\title{
O setor têxtil-confecções do Paraná e seus segmentos regionais especializados: 2000-2004
}

\author{
Maria Aparecida de Oliveira ${ }^{1}$ \\ Marcia Regina Gabardo da Câmara ${ }^{2}$ \\ Josil Rocio Voidela Baptista ${ }^{3}$
}

\begin{abstract}
Resumo: O objetivo do artigo é discutir o comportamento do setor têxtilconfecções do Paraná e seus segmentos regionais especializados no período 2000-2004. O estudo procura caracterizar a especialização produtiva e articular as etapas existentes da cadeia têxtil-confecções nas regiões especializadas. São analisados as características e mudanças estruturais do setor e os elementos constitutivos de Arranjos Produtivos Locais (APL). Os resultados mostram que o grupo têxtil paranaense perde importância após a crise da cotonicultura no estado nos anos 1990, com exceção da fiação de seda, que se mantém resistente, com poucos avanços. O grupo confecções apresenta forte dinamismo, particularmente no chamado "Corredor da Moda" no norte-noroeste do Estado, constituindo-se no maior produtor de jeans e bonés do país.
\end{abstract}

Palavras-chave: Setor têxtil-confecções; arranjos produtivos locais; distribuição econômica regional.

\footnotetext{
1 Mestre em Economia pela Universidade Estadual de Maringá (UEM), Economista e Pesquisadora do Instituto Paranaense de Desenvolvimento Econômico e Social (IPARDES). E-mail: cida_oliveira@terra.com.br.

2 Doutora em Teoria Econômica pelo IPE/FEA/USP, Docente do Departamento de Economia da Universidade Estadual de Londrina (UEL) e PPA-UEL/UEM. E-mail: mgabardo@uel.br.

3 Mestre em Desenvolvimento Econômico pela UFPR, Economista e Pesquisadora do Instituto Paranaense de Desenvolvimento Econômico e Social (IPARDES). E-mail: josil@pr.gov.br.
} 


\title{
The textile-clothing industry in Paraná and its specialized regional parts: 2000- 2004
}

\begin{abstract}
The present article discusses the performance of the textile-clothing sector in Paraná and its specialized regional segments between 2000 and 2004. The study seeks to characterize the productive specialization and identify the existing stages of the textile-clothing chain in the State specialized regions. The article analyzes the changes in the sector structure and the elements composing the Local Productive Arrangements. The results show that the importance of the Paraná textile group has decreased after the cotton culture crisis in 1990, except for silk production that still resists despite little improvement. The clothing group has improved greatly, mainly concerning the so called "Fashion Corridor" in the north/northwest side of the State where we can find the most important jeans and cap producers in Brazil.
\end{abstract}

Key words: Textile-clothing sector; local productive arrangements; regional economic distribution.

JEL: L67, O17, R12

\section{Introdução}

O setor têxtil-confecções paranaense apresenta-se com destaque, tanto na geração de emprego e renda no âmbito do Estado do Paraná, como também em função de sua representatividade crescente na especialização produtiva em alguns segmentos, com relevância nacional, dentre os quais destacam-se algumas aglomerações de empresas paranaenses especializadas na produção de confecções em jeans (localizadas em Maringá, Londrina e Cianorte), além do APL bonés de Apucarana, responsável por $86 \%$ da produção nacional deste acessório.

A despeito da crise desencadeada pela abertura comercial promovida pelo governo Collor, na década de noventa - a qual desestabilizou todo o setor confeccionista brasileiro -, o segmento têxtil-confecções paranaense reestruturou-se. Atualmente apresenta-se como estratégico para a política industrial do Estado, em função do impacto na geração de emprego e renda locais. O segmento concentra cerca de 4.647 empresas, as quais empregam 67.426 trabalhadores industriais, representando 14,0\% da mão-de-obra industrial ocupada no Estado. Ele é o segundo maior gerador de empregos no âmbito estadual - o primeiro é o complexo madeireiro. O conjunto das empresas confeccionistas paranaenses produz cerca de 216 milhões de peças por ano e fatura anualmente R\$3,5 bilhões (Exportação 2005). 
Dada a relevância do segmento, o presente artigo pretende discutir o comportamento do setor têxtil-confecções do Paraná e seus segmentos regionais especializados no período 2000-2004. A partir da identificação, sistematização e análise da evolução dos principais indicadores das aglomerações produtivas relevantes, o artigo propõe-se a apresentar uma visão panorâmica do setor e uma melhor visualização dos potenciais e das fragilidades deste importante setor produtivo paranaense.

Os procedimentos metodológicos envolvidos para a realização do estudo envolvem uma revisão teórica das contribuições que versam sobre aglomerações produtivas e arranjos produtivos locais, centrando a análise em autores que destacam a ação ativa do governo (micro, meso e macro regional) no processo de desenvolvimento e na ação da governança. $\mathrm{O}$ estudo procura caracterizar a especialização produtiva a partir do uso tradicional de quocientes locacionais (QL). O artigo realiza uma contribuição original ao articular as etapas existentes da cadeia têxtil-confecções nas regiões analisadas, utilizando vários índices tradicionais para a análise qualitativa e complementar ao QL, os quais permitem identificar mudanças estruturais apontando as regiões. O estudo é importante para a pesquisa regional e industrial paranaense porque adota uma postura sistêmica de análise conjunta de vários arranjos produtivos locais do Paraná, os quais apresentam vantagens de aglomeração. O artigo está estruturado em seis partes, além desta introdução. A segunda parte apresenta os elementos teóricos da análise; a terceira seção discute os procedimentos metodológicos; a quarta traz um panorama do setor têxtil-confecções; a quinta analisa as regiões especializadas paranaenses e, finalmente, a última apresenta as conclusões.

\section{Aglomerações produtivas especializadas}

Os clusters ou arranjos produtivos locais são aglomerações territoriais de agentes econômicos, políticos e sociais cujo foco encontra-se em um conjunto específico de atividades econômicas que podem apresentar vínculos, mesmo que estes sejam incipientes (Albagli \& Brito 2003; Cassiolato \& Lastres 2003). Eles se caracterizam pela concentração de empresas setorialmente especializadas, normalmente de pequeno e médio portes, cuja produção tende a ocorrer de forma verticalmente desintegrada, uma vez que as firmas especializam-se em diferentes partes do processo produtivo, onde as relações fornecedores-clientes realizadas entre firmas reforçam os elos interfirmas para frente e para trás na cadeia produtiva (Hagueauer \& Prochnik 2000). Prochnik (2001) afirma que em um nível mais agregado e geograficamente localizado, distritos industriais e pólos industriais são, na prática, aglomerações 
urbanas e conjuntos de instituições em torno de uma cadeia produtiva que sugerem a especialização de uma região em determinada atividade.

Schmitz (2000) classifica quatro linhas de pensamento distintas sobre o assunto aglomerações produtivas: i) Nova Geografia Econômica; ii) Economia de Empresas; iii) Ciência Regional, onde se destacam autores como Markusen (1996), Pyke \& Sengenberger (1992) e Storper (1995); iv) literatura da inovação, com destaque para autores como Lundvall (1993), Edquist (1997) e Freeman (1995).

Suzigan (2003) destaca a importância da articulação e da governança no desenvolvimento das aglomerações produtivas especializadas. Ele define governança em arranjos produtivos locais como a capacidade de coordenação ou comando que os diversos agentes envolvidos exercem sobre as inter-relações produtivas, comerciais, tecnológicas, entre outras, as quais influenciam o desenvolvimento de tal arranjo. Apoiandose em Humphrey \& Schmitz (1998), Vargas (2000) e Suzigan et al. (2003), Campos (2004) afirma que a estrutura de governança associa-se a uma relação de poder que um determinado agente detém dentro de um determinado sistema produtivo, em função das assimetrias observadas entre os agentes deste sistema produtivo, acelerando o desenvolvimento regional.

As aglomerações industriais são caracterizadas por fatores relacionados à dimensão territorial, à diversidade de atividades e atores econômicos, políticos e sociais, ao conhecimento tácito, aos processos de inovação e aprendizado interativo, às formas de governança e o grau de imersão ou enraizamento, que revestem questões culturais (Lastres \& Cassiolato 2004). A governança permite analisar a influência dos atores - agentes locais ou externos - na coordenação dos sistemas de produção e na trajetória de desenvolvimento de capacitação produtiva e de inovação empresarial, visto que disseminam práticas democráticas de resolução de problemas, estimulando a intervenção e a participação dos múltiplos atores nos processos de decisão local.

Segundo Albagli \& Britto (2003), há duas formas de governança: a hierárquica e aquela na forma de "redes". A primeira é caracterizada por apresentar autoridade internalizada em grandes empresas. A governança na forma de "redes" é caracterizada pela ausência de grandes empresas coordenando as atividades econômicas e tecnológicas. A governança do tipo hierárquica, segundo Markusen (1996), pode envolver aglomerações onde há a presença de: a) uma ou algumas grandes empresas que funcionam como "âncora" para a economia da região - são as chamadas aglomerações hub-and-spoke ou "centro-radiais" (Santos et al. 2002); b) plantas industriais de empresas cujas sedes encontram-se fora do aglomerado, denominadas de "plataforma industrial satélite". Nesse caso, decisões de investimento se dão fora do aglomerado e as empresas 
"plataforma satélites" podem ficar "espacialmente independentes das operações para frente e para trás da cadeia produtiva" (Cassiolato \& Lastres 2001).

Edquist (2001) discute a importância dos Sistemas de Inovações (SI), que devem produzir, difundir e usar inovações e podem ser supranacionais, nacionais e subnacionais (regional, local), e podem ser ainda setoriais dentro dessas demarcações geográficas. As organizações e instituições ${ }^{4}$ são os componentes principais de um sistema de inovação, porém a especificação desses componentes varia entre os sistemas. Segundo Pyke (1992), o sistema de cooperação ocorre entre empresas normalmente pequenas e independentes, que, juntas, se fazem valer das instituições locais, através de relacionamentos de competição e cooperação. A cooperação colabora para o atendimento de inúmeras necessidades das empresas pertencentes ao mesmo conglomerado, as quais não seriam atendidas se as empresas atuassem isoladamente.

\section{Metodologia}

O quadro 1 apresenta os elementos utilizados na análise dos segmentos especializados no setor têxtil-confecções do Paraná.

$\mathrm{Na}$ metodologia utilizada para identificar e selecionar as aglomerações especializadas, foram utilizados os dados de emprego da Relação Anual de Informações Sociais do Ministério do Trabalho (RAIS/MTE) e do Valor Adicionado Fiscal (VAF) da Secretaria de Estado da Fazenda do Paraná (SEFA). Essas informações foram formatadas em segmentos-região definidos em Ipardes (2003) e reformuladas em Oliveira (2005), que foram submetidos a procedimentos que consistiram de três etapas: a primeira, de cálculos dos quocientes locacionais, que é uma ferramenta tradicional utilizada em estudos de economia regional para indicar espaços regionais especializados em determinadas atividades, neste caso utilizando-se da nomenclatura QLE para empregos e QLV para VAF; a segunda etapa com classificação tipológica; e a terceira com filtros seletivos cujos procedimentos foram os seguintes: a) cálculo dos QLEs para todos segmentos-região; soma de todos os QLEs dos segmentos-região (=100\%) e, finalmente, cálculo da participação relativa do segmentoregião no total de QLE para empregos.

Para o cálculo dos QLs, utilizou-se a seguinte fórmula: $Q L \frac{S R_{i j}}{T R_{j}} \frac{T E}{S E_{i}}$

4 Organizações são estruturas formais com um objetivo explícito e são criadas conscientemente. As Instituições são conjuntos de hábitos comuns, rotinas, práticas estabelecidas, regras ou leis que regulam as relações e inter-relações entre indivíduos e organizações. 
Onde:

$\mathrm{SR}_{\mathrm{ij}}=$ Total de empregos ou valor adicionado do segmento i na região $\mathrm{j}$; $\mathrm{TR}_{\mathrm{j}}=$ Total de empregos ou valor adicionado na região $\mathrm{j}$;

$\mathrm{SE}_{\mathrm{i}}=$ Total de empregos ou valor adicionado do segmento i no Estado; $\mathrm{TE}=$ Total de empregos ou valor adicionado do Estado

Os segmentos-região especializados (QLs > 1) foram classificados em Baixa, Média e Alta Especialização, adotando: i) Baixa Especialização para participação no QL total entre $0 \%$ e 25\%; ii) Média Especialização para participação no QL total entre 26\% e 50\%; e, iii) Alta Especialização para participação no QL total maior que 50\%. Os mesmos cálculos e tipologia também foram aplicados para o Valor Adicionado (VA) e determinação dos QLVs. Foram validados todos os segmentos com alta e média especialização. Já segmentos com baixa especialização foram validados somente após "um ponto de corte", cujo parâmetro consistia na existência de um número mínimo de estabelecimentos localizados na região, assim determinado: têxtil de algodão (10 estabelecimentos), têxtil de rami, seda e de outras fibras naturais (10), têxtil de fibras artificiais (5), malharia, linhas, tapeçaria e outros têxteis (40), vestuário (150), bonés, brindes e outros artefatos de tecidos (100), estamparia, texturização e outros acabamentos em tecidos (12) e uniformes e vestuário de segurança (20 estabelecimentos).

QUADRO 1. ELEMENTOS DE ANÁLISE DOS SEGMENTOS ESPECIALIZADOS

\begin{tabular}{|c|c|c|}
\hline área & variáveis & Fonte informações \\
\hline Estrutura produtiva & $\begin{array}{l}\text { No. de estabelecimentos, empregados, VAF, } \\
\text { produção }\end{array}$ & SEFA, RAIS, jornais, sites \\
\hline Especialização & Produtos, modo de produção & SEFA, RAIS, jornais, sites \\
\hline Economias externas & $\begin{array}{l}\text { Adensamento das cadeias (fornecedoras, empresas } \\
\text { correlatas, de apoio, cadeia de valor) }\end{array}$ & SEFA, RAIS, jornais, sites \\
\hline Mercado & $\begin{array}{l}\text { Destino das vendas, canais de venda, eventos, } \\
\text { inserção regional, nacional e internacional }\end{array}$ & IEMI, OMC \\
\hline Mão-de-obra & $\begin{array}{l}\text { Grau de instrução, salários médios, idade, gênero, } \\
\text { educação formal, cursos de capacitação }\end{array}$ & $\begin{array}{l}\text { RAIS, Instituições de ensino e de } \\
\text { formação }\end{array}$ \\
\hline Tecnologia & Nível tecnológico, atividades e esforços em P\&D\&I & Estudos de caso \\
\hline Gestão empresarial & Cursos e atividades de apoio & SEBRAE, FIEP \\
\hline Apoio institucional & Programas, projetos, atividades-ponte & Governo, instituições \\
\hline Papel do Estado & Neutro, estruturador, promotor, indutor & Estudos de caso, sites, jornais \\
\hline Gestão APL & $\begin{array}{l}\text { Comitê gestor, comissões temáticas, atividades, } \\
\text { conquistas, eventos, interação, parcerias }\end{array}$ & SEFA, RAIS, jornais, sites \\
\hline Ambiente inovador & $\begin{array}{l}\text { Instituições, parcerias universidade/ empresa, } \\
\text { projetos tecnológicos, estrutura de informações } \\
\text { organizadas }\end{array}$ & $\begin{array}{l}\text { SEFA, RAIS, jornais, sites, estudos } \\
\text { de caso }\end{array}$ \\
\hline $\begin{array}{l}\text { Identidade social e } \\
\text { cultural }\end{array}$ & $\begin{array}{l}\text { Simbologia social e econômica, iniciativas locais, } \\
\text { protagonismo local }\end{array}$ & Documentos, sites, jornais \\
\hline Eficiência Coletiva & $\begin{array}{l}\text { Parcerias, joint venture, consórcios, pool de } \\
\text { exportação, cooperativas produtiva, centrais de } \\
\text { compra e venda }\end{array}$ & Estudos de caso, jornais, sites \\
\hline Perspectivas & $\begin{array}{l}\text { Investimentos anunciados, estratégias e ações } \\
\text { coletivas }\end{array}$ & Jornais, sites \\
\hline
\end{tabular}

Elaboração das autoras. 


\section{Panorama do setor têxtil-confecções}

A atividade têxtil instalou-se efetivamente no Brasil no período 18441913, segundo Monteiro Filho \& Santos (2002), e sofreu grandes mudanças ao longo do século XX. Analisando período recente, particularmente os anos 90 merecem destaque, uma vez que indústria têxtil brasileira, segundo Kupfer (1998), reagiu de forma lenta aos choques no ambiente competitivo - abertura de mercados promovida pelo governo Collor. Campos et al. (2000) destacam que a abertura e o incremento da participação dos países asiáticos no mercado internacional de têxteis-confecções configuraram um quadro de crise setorial.

Kupfer (1998) afirma que a sobrevivência do setor frente às mudanças no quadro competitivo nos anos 90 ocorreu graças aos esforços de compressão de custos industriais, paralelamente a ganhos de qualidade e produtividade. A participação de pequenas e médias empresas é elevada no setor têxtil-confecções brasileiro, a maioria voltada à atuação regional e operando com um parque fabril atrasado tecnologicamente.

Gorini (2000) afirma que a abertura da economia e o Plano Real influenciaram a cadeia têxtil-confecções no Brasil, incorrendo em aumento da concentração na produção têxtil e pulverização da produção nas confecções. O volume elevado de investimentos na indústria têxtil incrementou a relação capital produto, enquanto na indústria de confecções, intensiva em mão-de-obra, a mesma tendência não foi observada. A reestruturação redundou na falência e fechamento de firmas mais defasadas tecnologicamente, como no caso dos produtores de tecidos artificiais que concorriam com os produtos importados da Ásia, bem como na substituição da produção de tecidos planos pelas malhas de algodão, cujos custos são menores. O parque produtivo nordestino prosperou em função dos menores custos de mão-de-obra e as empresas alteraram o conjunto de produtos ofertados - verificou-se incremento na escala produtiva e redução da variedade produtiva. Muitas empresas ampliaram a terceirização, buscando a diferenciação dos produtos e melhorias na comercialização - gerenciamento da marca, melhorias na logística, proximidade com a clientela final via franquias, lojas próprias; outras passaram a atuar em redes, enquanto outras ampliaram sua participação no mercado externo.

A cadeia produtiva têxtil-confecções está dividida em cinco segmentos principais: a) Fiação; b) Tecelagem; c) Malharia; d) Acabamento e beneficiamento e e) Confecção. A divisibilidade das atividades na cadeia têxtil-confecções possibilita uma estrutura produtiva fragmentada e uma estrutura industrial com grande diversidade de tamanho das unidades produtivas e diferentes graus de integração vertical das empresas (Gorini 2000). Segundo Arbex (2005), entre 1990 e 2004 o investi- 
mento foi intensificado na cadeia têxtil-confecções no Brasil: a fiação investiu US \$2,8 bilhões, as confecções investiram US\$ 1,9 bilhão, o setor de tecelagem e malharia, US $\$ 1,6$ bilhão (cada um) e o beneficiamento, US $\$ 1,7$ bilhão.

Com dados de 1995, foi possível verificar a posição da cadeia têxtilvestuário e das regiões especializadas no Paraná: através da análise dos índices de Rasmussen-Hirschman calculados por Rodrigues et al. (2005), os indicadores para frente sinalizam que o setor têxtil é o nono em importância e para trás é o décimo sexto.

Em 2003, o Brasil produziu 1,5 mil toneladas de fios de seda (2\% da produção mundial), sendo 90\% deste total destinado à exportação, predominantemente para o Japão (Guerin 2004). O Paraná é o maior produtor nacional de casulos verdes (cerca de 90\%), sendo responsável por $53 \%$ da industrialização, através de três grandes empresas de fiação: a Cooperativa Cocamar (Maringá), a Bratac (Londrina) e a Kanebo Silk do Brasil (Cornélio Procópio). A sericicultura tem apresentado avanços no Paraná; em 2004, a exploração da atividade integrou no Paraná 6.535 agricultores familiares, com 7.343 barracões e área de 21,5 mil hectares de cultivo da amoreira - produção de 9,2 mil toneladas de casulos (Encontro 2004).

Enquanto a sericicultura cresceu no Paraná, a cotonicultura perdeu dinamismo na década de noventa, gerando uma crise oriunda da concorrência externa, dos problemas climáticos e das pragas nas lavouras, além do fato de que a maioria dos empreendimentos estavam sendo atraídos para as áreas de expansão agrícola, no oeste do país. Na década de 1980, o Paraná posicionou-se como o principal produtor de algodão do país. Em 1985 foi responsável pela produção de 1 milhão de toneladas (540 hectares plantados) em 1991 chegou a um milhão de toneladas (615 mil hectares plantados) e em 1995 a produção caiu para 487 mil toneladas (297 mil hectares plantados). Abrupta queda ocorreu em 1999, passando a 109 mil toneladas (48 mil hectares plantados) e, em 2004, em conseqüência da crise, a área total plantada no Estado foi de apenas 47 mil hectares, gerando uma produção de 90 mil toneladas (SEAB/ DERAL 2004). Na tentativa de reverter este quadro, o segmento de beneficiamento e industrialização do algodão contou com incentivos fiscais do Governo do Estado do Paraná. A alíquota de recolhimento do Imposto sobre Industrialização de Mercadorias e Serviços (ICMS) na venda de algodão em pluma (alíquota de $12 \%$ ) passa a ter redução de $50 \%$ na venda fora do Estado e 80\% nas vendas internas (Governo 2004).

A atividade de tecelagem o Estado do Paraná conta com apenas três unidades fabris de tecidos planos instaladas no Estado, sendo elas a Textilpar (brim), em Paranavaí, a Têxtil Apucarana (sarja), em Apucarana e a Charlex (elastano), em Curitiba. 
Por outro lado, no segmento de confecções, o Estado do Paraná vem conquistando posto de destaque na indústria da moda nacional, visto que se firmara, em 2003, como o segundo maior pólo industrial de confecção do país, com produção estimada em 216 milhões de peças por ano e faturamento anual de $\mathrm{R} \$ 3,5$ bilhões (FIEP 2005). Nos últimos anos, o vestuário tem apresentado acelerado crescimento em número de estabelecimentos e em número de postos de trabalho ofertados. O crescimento mais acentuado foi observado entre 1985 e 1990, quando sua participação no emprego industrial do Estado passou de 1,6\% para $5,7 \%$. O crescimento também foi elevado no período de 1995 a 2000, o qual passou de $5,4 \%$ para $8,5 \%$, e em 2002 passou para $9,3 \%$ (Oliveira \& Maia 2004).

\section{Regiões especializadas no setor têxtil-confecções -}

Os elevados quocientes locacionais de emprego e valor adicionado permitiram identificar duas regiões especializadas na área têxtil de algodão: Cornélio Procópio-Bandeirantes e Campo Mourão-Goioerê. Destacam-se como regiões especializadas em têxtil de rami, seda e outras fibras as regiões de Cornélio Procópio-Bandeirantes e Londrina-Cambé, em menor grau. A produção de malhas, linhas e tapeçaria é representativa em três regiões: Londrina-Cambé, Apucarana-Ivaiporã e MaringáSarandi. Seis regiões destacam-se na produção de vestuário e acessórios: Londrina-Cambé, Apucarana-Ivaiporã, Maringá-Sarandi, Umuarama-Cianorte, estas quatro localizadas no "Corredor da Moda" do norte-noroeste do Estado. As regiões de Francisco Beltrão-Pato Branco (sudoeste do Estado) e Toledo-Marechal Cândido Rondon (oeste) também destacam-se neste segmento, além das aglomerações municipais de moda bebê de Terra Roxa e de malhas de Imbituva.

A análise da representação dos segmentos-região especializados no âmbito estadual em termos de VAF estadual permite verificar que os segmentos do vestuário das regiões Maringá-Sarandi, UmuaramaCianorte e Londrina-Cambé participam com $0,2 \%$, cada uma; a representatividade é similar ao segmento de têxtil de algodão da região de Maringá-Sarandi (o,2\%). Em termos de emprego, segundo a tabela 1, os segmentos do vestuário da região de Umuarama-Cianorte $(2,0 \%)$ e da região Maringá-Sarandi $(1,9 \%)$ detêm as maiores participações no total de empregos do Estado do setor têxtil-confecções.

As principais aglomerações do setor têxtil-confecções localizam-se em duas posições espaciais no Estado do Paraná. Primeiro, no chamado "Corredor da Moda", eixo Londrina-Apucarana-Maringá-Cianorte (norte e o nordeste do Paraná), que é constituído por uma aglomeração de 
empresas do chamado complexo vestimentar - beneficiamento, fiação, tecelagem, vestuário, uniformes, bonés e lavanderias e serviços de acabamento -, que vem adquirindo importância nacional como o maior produtor de jeans e de bonés do país. Os outros espaços estão mais pulverizados e são formados pelas aglomerações produtivas localizadas no sudoeste do Estado (roupas masculinas) e, no caso do têxtil de algodão e têxtil de rami, seda e de outras fibras nas regiões de CornélioProcópio-Bandeirantes (norte pioneiro) e de Campo Mourão-Goioerê (centro oriental).

Em termos institucionais, o setor têxtil-confecções começou a se organizar com a criação da Associação Paranaense da Indústria Têxtil e do Vestuário (VESTPAR) em 1992. Esta entidade reúne 9 sindicatos e tem o objetivo de unificar as ações e gerar desenvolvimento para o setor têxtil-confecções do Paraná.

A articulação institucional permitiu a realização de vários eventos que movimentaram o setor têxtil-confecções paranaense a partir de 2000. O mais importante deles é o Paraná Fashion, que contou, em 2005, com R \$ 1,5 milhão para a realização do evento em Maringá e que foi patrocinado pela Têxtil Canatiba Jeanswear e contou com apoio do Governo do Estado, da Associação Brasileira da Indústria Têxtil (Abit), da Agência de Promoção de Exportações do Brasil (Apex) e de outras 13 empresas ou organizações (PR Fashion 2005). Os eventos regionais mais importantes são: o Curitiba Fashion Business e a Feira de Fornecedores da Indústria de Confecção (CONFTEC), em Curitiba; o Fashion Art e o Estação Fashion, em Londrina; o Estação Fashion, em Maringá; a Expovest, em Cianorte; a ExpoBoné, em Apucarana, a WestFashion, em Cascavel; a Sudoeste Mostra Moda, em Pato Branco, e a Feira de Malhas de Imbituva (FEMAI).

Em 2005, realizou-se uma série de seminários sobre a Competitividade da Cadeia do Vestuário, promovidos pelo Governo do Estado e ministrados pelos consultores do Instituto de Estudos e Marketing Industrial (IEMI) em Curitiba, Londrina, Maringá, Cascavel e Francisco Beltrão. Neste mesmo ano, iniciaram as missões comerciais - Circuit Business Fashion no Chile; Semana do Paraná em Paris (França); visitas técnicas à Argentina, além de recepções de delegações de empresários estrangeiros. 
OLIVEIRA, M. A. et al. O setor têxtil-confecções do Paraná...

TABELA 1. NÚMERO DE ESTABELECIMENTOS E DE EMPREGADOS, PARTICIPAÇÃO NO VALOR ADICIONADO FISCAL, QUOCIENTES LOCACIONAIS DE EMPREGOS (QLE) E DE VALOR ADICIONADO (QLV) NO SETOR TÊXTIL - VESTUÁRIO DO ESTADO DO PARANÁ $-2004$

\begin{tabular}{|c|c|c|c|c|c|c|c|c|c|}
\hline \multirow[t]{2}{*}{ Segmento } & \multirow[t]{2}{*}{ Região } & \multirow[t]{2}{*}{$\begin{array}{l}\text { No. } \\
\text { Estabelecimentos }\end{array}$} & \multicolumn{3}{|c|}{ Empregados } & \multicolumn{2}{|c|}{ Valor adicionado } & \multicolumn{2}{|c|}{$\begin{array}{c}\text { Quocientes } \\
\text { locacionais (1) }\end{array}$} \\
\hline & & & Abs. & \begin{tabular}{c|} 
Região \\
\end{tabular} & $\begin{array}{c}\text { Esta-do } \\
\%\end{array}$ & $\begin{array}{c}\text { Região } \\
\%\end{array}$ & $\begin{array}{c}\begin{array}{l}\text { Esta- } \\
\text { Do } \\
\%\end{array} \\
\%\end{array}$ & Qle & \\
\hline têxtil de algodão & $\begin{array}{l}\text { Cornélio Procópio- } \\
\text { Bandeirantes }\end{array}$ & 10 & 361 & 5,7 & 0,1 & 8,6 & 0,1 & 7,0 & $\overline{15,1}$ \\
\hline têxtil de algodão & $\begin{array}{l}\text { Campo Mourão- } \\
\text { Goioerê }\end{array}$ & 15 & 347 & 3,6 & 0,1 & 18,3 & 0,1 & 4,5 & 32,2 \\
\hline Total especializado & & 25 & 708 & & $\mathbf{0 , 1}$ & & $\mathbf{0 , 2}$ & & \\
\hline Total têxtil de algodão & & 76 & 3.896 & & 0,8 & & 0,6 & & \\
\hline $\begin{array}{l}\text { têxtil de rami, seda e de } \\
\text { outras fibras naturais }\end{array}$ & $\begin{array}{l}\text { Cornélio Procópio- } \\
\text { Bandeirantes }\end{array}$ & 3 & 855 & 13,4 & 0,2 & 6,1 & 0,0 & 35,5 & 57,8 \\
\hline $\begin{array}{l}\text { têxtil de rami, seda e de } \\
\text { outras fibras naturais }\end{array}$ & Londrina-Cambé & 13 & 647 & 1,1 & 0,1 & 0,7 & 0,0 & 3,0 & 6,9 \\
\hline Total Especializado & & 16 & 1.502 & & $\mathbf{0 , 3}$ & & $\mathbf{0 , 1}$ & & \\
\hline $\begin{array}{l}\text { Total têxtil de rami, seda e } \\
\text { de outras fibras naturais }\end{array}$ & & 45 & 1.822 & & $\mathbf{0 , 4}$ & & $\mathbf{o , 1}$ & & \\
\hline têxtil de fibras artificiais & $\begin{array}{l}\text { Metropolitana Sul- } \\
\text { Curitiba }\end{array}$ & 4 & 473 & 0,3 & 0,1 & 0,3 & 0,2 & 3,1 & 1,7 \\
\hline Total especializado & & 4 & 473 & & $\mathbf{0 , 1}$ & & $\mathbf{0 , 2}$ & & \\
\hline Total de fibras artificiais & & 4 & 473 & & $\mathbf{0 , 1}$ & & $\mathbf{0 , 2}$ & & \\
\hline $\begin{array}{l}\text { Malharia, linhas, tapeçaria e } \\
\text { outros têxteis }\end{array}$ & Londrina-Cambé & 60 & 839 & 1,5 & 0,2 & 0,2 & 0,0 & 1,2 & 0,7 \\
\hline $\begin{array}{l}\text { Malharia, linhas, tapeçaria e } \\
\text { outros têxteis }\end{array}$ & Apucarana-Ivaiporã & 48 & 501 & 3,0 & 0,1 & 2,2 & 0,0 & 2,4 & 10,4 \\
\hline $\begin{array}{l}\text { Malharia, linhas, tapeçaria e } \\
\text { outros têxteis }\end{array}$ & Maringá-Sarandi & 59 & 590 & 1,5 & 0,1 & 0,3 & 0,0 & 1,2 & 1,6 \\
\hline Total especializado & & 167 & 1.930 & & $\mathbf{0 , 4}$ & & $\mathbf{o , o}$ & & \\
\hline $\begin{array}{l}\text { Total malharia, linhas, } \\
\text { tapeçaria e outros têxteis }\end{array}$ & & 536 & 5.994 & & 1,2 & & $\mathbf{0 , 2}$ & & \\
\hline Vestuário & Londrina-Cambé & 362 & 6.920 & 12,2 & 1,4 & 3,2 & 0,2 & 1,3 & 2,8 \\
\hline Vestuário & Apucarana-Ivaiporã & 219 & 2.870 & 17,2 & 0,6 & 4,4 & 0,1 & 1,8 & 3,8 \\
\hline Vestuário & Maringá-Sarandi & 699 & 9.251 & 24,0 & 1,9 & 7,3 & 0,2 & 2,5 & 6,4 \\
\hline Vestuário & $\begin{array}{l}\text { Umuarama- } \\
\text { Cianorte }\end{array}$ & 712 & 9.562 & 35,0 & 2,0 & 13,4 & 0,2 & 3,6 & 11,8 \\
\hline Vestuário & $\begin{array}{l}\text { Toledo-Marechal } \\
\text { Cândido Rondon }\end{array}$ & 178 & 2.969 & 11,5 & 0,6 & 2,8 & 0,1 & 1,2 & 2,5 \\
\hline Vestuário & $\begin{array}{l}\text { Francisco Beltrão- } \\
\text { Pato Branco }\end{array}$ & 169 & 5.292 & 24,6 & 1,1 & 8,0 & 0,1 & 2,5 & 7,0 \\
\hline Total especializado & & 2.339 & 36.864 & & 7,6 & & $\mathbf{0 , 9}$ & & \\
\hline Total vestuário & & 3.252 & 46.704 & & 9,7 & & $\mathbf{1 , 1}$ & & \\
\hline $\begin{array}{l}\text { bonés, brindes e outros } \\
\text { artefatos de tecidos }\end{array}$ & Apucarana-Ivaiporã & 141 & 2.125 & 12,7 & 0,4 & 6,8 & 0,1 & 14,6 & 34,4 \\
\hline Total especializado & & 141 & 2.125 & & 0,4 & & $\mathbf{0 , 1}$ & & \\
\hline $\begin{array}{l}\text { Total bonés, brindes e } \\
\text { outros artefatos } \\
\text { têxteis }\end{array}$ & & 377 & 4.188 & & $\mathbf{0 , 9}$ & & $\mathbf{0 , 2}$ & & \\
\hline $\begin{array}{l}\text { Estamparia, texturização e } \\
\text { outros acabamentos em } \\
\text { tecidos }\end{array}$ & Maringá-Sarandi & 21 & 258 & 0,7 & 0,1 & 0,4 & 0,0 & 2,6 & 1,1 \\
\hline Total especializado & & 21 & 258 & & $\mathbf{0 , 1}$ & & $\mathbf{o , o}$ & & \\
\hline $\begin{array}{l}\text { Total estamparia, } \\
\text { texturização e outros } \\
\text { acabamentos em tecidos }\end{array}$ & & 196 & 1.250 & & $\mathbf{0 , 3}$ & & 0,4 & & \\
\hline $\begin{array}{l}\text { Uniformes e vestuário de } \\
\text { segurança }\end{array}$ & Apucarana-Ivaiporã & 15 & 1.297 & 7,8 & 0,3 & 4,7 & 0,1 & 12,1 & 23,5 \\
\hline $\begin{array}{l}\text { Uniformes e vestuário de } \\
\text { segurança }\end{array}$ & Maringá-Sarandi & 24 & 274 & 0,7 & 0,1 & 0,4 & 0,0 & 1,1 & 1,8 \\
\hline Total especializado & & 39 & 1.571 & & $\mathbf{0 , 3}$ & & $\mathbf{0 , 1}$ & & \\
\hline $\begin{array}{l}\text { Total uniformes e } \\
\text { vestuário de segurança }\end{array}$ & & 161 & 3.099 & & 0,6 & & $\mathbf{0 , 2}$ & & \\
\hline $\begin{array}{l}\text { Total setor têxtil- } \\
\text { confecções Paraná }\end{array}$ & & 4.647 & 67.426 & & 14,0 & & $3, \mathbf{o}$ & & \\
\hline
\end{tabular}

FONTE: MTE/RAIS. Elaboração das autoras. 
As parcerias externas estabelecidas em prol do desenvolvimento do setor têm conta com o Serviço Brasileiro de Apoio às Micro e Pequenas Empresas (SEBRAE), Governo do Estado do Paraná, Sistema da Federação das Indústrias do Estado (FIEP), Banco Regional de Desenvolvimento do Extremo Sul (BRDE), Banco Nacional de Desenvolvimento Econômico e Social (BNDES) e Universidades. Também são realizadas parcerias para os cursos de formação e profissionalizantes do Serviço Nacional de Aprendizagem Industrial (SENAI) e as Clínicas Tecnológicas da Rede Tecnológica (SENAI/RETEC).

\subsection{Aglomerações especializadas do corredor da moda}

\section{Região de Apucaran-Ivaiporã}

A Região de Apucarana-Ivaiporã é constituída por 29 municípios. A projeção populacional do IBGE em 2005 para a região foi de aproximadamente 345 mil habitantes, dos quais 70,7\% residentes na área urbana.

Em 2004, em 441 estabelecimentos industriais, o setor têxtil-confecções da região empregava 72.218 empregados $(42,8 \%$ da mão-de-obra industrial da região) e representava 19,3\% do VAF regional.

A maior aglomeração de bonés, brindes e outros artefatos de tecidos do Brasil está instalada na região, com 141 estabelecimentos, que produzem 44 milhões de bonés por ano, representando $86 \%$ do total da produção de bonés do país, rendendo à cidade de Apucarana o titulo de "Capital Nacional do Boné". No Censo Industrial realizado pelo IPARDES em 2006 no APL, constatou-se a presença de 398 empresas faccionistas que atuam no segmento. O Arranjo Produtivo Local, composto majoritariamente por pequenas e microempresas, faz parte dos 11 APLs selecionados a nível nacional pelo Ministério de Desenvolvimento e Comércio Exterior (MDIC) e tem se destacado pela governança atuante e pelo êxito na obtenção apoio de várias instituições, a exemplo do projeto "Aba sem memória", que será desenvolvido por empresas e instituições locais e financiado pela Financiadora de Projetos (Finep), instituição ligada ao Ministério e Ciência e Tecnologia (MCT). O projeto prevê pesquisas em materiais com propriedades e ligas que forneçam uma aba sem molde, um material que tenha grande tração e flexão, mas com custo baixo (Ipardes 2006). Sobressaem-se as empresas: Sul Americano, STO, Estação, Gouveia, Art \& Co e GO Bonés, todas em Apucarana. A participação do segmento no total do VAF industrial da região elevouse de 6,1\%, em 2000 para 6,8\% em 2004 (tabela 2).

Em relação à mão-de-obra do segmento bonés, brindes e outros artefatos de tecidos, verificou-se expressiva elevação no número de postos 
de trabalho, passando de 1.308 empregados em 2000 para 2.125 em 2004, representando um incremento de $62,5 \%$. As vantagens de aglomeração ocasionaram a concentração de empresas e a geração de um número substantivo de empregos. No que tange à instrução dos trabalhadores do segmento bonés, brindes e outros artefatos têxteis, verificou-se a crescente participação dos trabalhadores que detinham o nível médio completo, cuja parcela passou de $15,4 \%$ do total dos empregados lotados no segmento em 2000, para 22,1\% em 2004. Quanto à remuneração dos trabalhadores lotados no segmento, a participação daqueles que auferem renda na faixa de 2 a 4 SMs altera-se substancialmente, passando de $16,0 \%$ em 2000 do total de trabalhadores desse segmento para $21,7 \%$ em 2004. No quesito faixa etária, cresce a participação dos trabalhadores entre 25 e 39 anos, os quais representam $39,7 \%$ em 2000 e 43,0\% em 2004. Embora as mulheres (56\% dos empregados) sejam a maioria, a participação expressiva dos homens (44,\%), em um comparativo regional do Estado, faz da região de Apucarana-Ivaporã a maior absorvedora de mão-de-obra masculina no segmento de confecções do Estado (RAIS/MTE 2004).

TABELA 2. NÚMERO DE ESTABELECIMENTOS, EMPREGADOS E PARTICIPAÇÃO NO VALOR ADICIONADO FISCAL (VAF) DO SETOR TÊXTIL-CONFECÇÕES DA REGIÃO DE APUCARANAIVAIPORÃ - 2000-2004

\begin{tabular}{|c|c|c|c|c|c|c|c|c|}
\hline \multirow[t]{3}{*}{ Segmento } & \multirow{2}{*}{\multicolumn{2}{|c|}{ Estabelecimentos }} & \multicolumn{4}{|c|}{ Empregados } & \multirow{2}{*}{\multicolumn{2}{|c|}{ Part. Vaf regional (\%) }} \\
\hline & & & \multicolumn{2}{|c|}{2000} & \multicolumn{2}{|c|}{2004} & & \\
\hline & 2000 & 2004 & abs. & $\%$ & abs. & $\%$ & 2000 & 2004 \\
\hline têxtil de algodão & 5 & 6 & 450 & 4,1 & 306 & 1,8 & 4,0 & 1,0 \\
\hline $\begin{array}{l}\text { malharia, linhas, tapeçaria } \\
\text { e outros têxteis }\end{array}$ & 29 & 48 & 182 & 1,7 & 501 & 3,0 & 0,4 & 2,2 \\
\hline vestuário & 177 & 219 & 2.228 & 20,2 & 2.870 & 17,2 & 3,4 & 4,4 \\
\hline $\begin{array}{l}\text { bonés, brindes e outros } \\
\text { artefatos de tecidos }\end{array}$ & 86 & 141 & 1.308 & 11,9 & 2.125 & 12,7 & 6,1 & 6,8 \\
\hline $\begin{array}{l}\text { estamparia, texturização e } \\
\text { outros acabamentos em } \\
\text { tecidos }\end{array}$ & 4 & 12 & 82 & 0,7 & 119 & 0,7 & 0,6 & 0,2 \\
\hline $\begin{array}{l}\text { uniformes e vestuário de } \\
\text { segurança }\end{array}$ & 8 & 15 & 498 & 4,5 & 1.297 & 7,8 & 4,4 & 4,7 \\
\hline Total tểxtil-confecções & 309 & 441 & 4.748 & 43,0 & 7.218 & 43,2 & 18,9 & 19,3 \\
\hline Demais Segmentos & 620 & 720 & 6.284 & $\mathbf{5 7}, \mathbf{0}$ & 9.497 & 56,8 & 81,1 & 80,7 \\
\hline Total da região & 929 & 1.161 & 11.032 & 100,0 & 16.715 & 100,0 & 100,0 & 100,0 \\
\hline
\end{tabular}

FONTE: RAIS/MTE, SEFA. Elaboração das autoras.

O segmento de vestuário na região está constituído por 219 confecções, capitaneadas pelas empresas: Novo Século, Kriswill, Blue Ocean e SD, em Apucarana; Astra, em Marilândia do Sul, e a DMS, em Jandaia do Sul. A participação do segmento no VAF industrial da região se elevou no período, passando de 3,4\% em 2000 para 4,4\% em 2004. 
A análise do perfil da mão-de-obra ocupada no segmento de vestuário na região revela o crescimento expressivo do número de postos de trabalho, passando de 2.228 em 2000 para 2.870 em 2004. Quanto ao grau de instrução, os dados revelam que houve aumento da participação daqueles com nível médio completo, passando de $15,1 \%$ do total de empregados do segmento em 2000 para 20,4\% em 2004. Houve ampliação da participação dos trabalhadores que auferem até SM - 57,8\% do total dos empregados do segmento em 2000 e 70,6\% em 2004. Há ampliação da participação dos trabalhadores que estão na faixa etária entre 25 e 39 anos, passando de 37,7\% em 2000 para 42,9\% em 2004. As mulheres aumentam sua participação no segmento, passando de 47,8\% em 2000 para 66,6\% em 2004 (RAIS/MTE 2004). Estes dados revelam que os novos postos de trabalhos criados foram ocupados em geral por mulheres jovens, auferindo salários inferiores aos trabalhadores lotados no segmento.

O segmento de uniformes e vestuário de segurança beneficia-se da oferta de mão-de-obra com tradição em confecção e do couro local. São 15 empresas atuantes no segmento e as mais importantes são as indústrias Fujiwara, Igarin, Segurpar e Braço Forte, em Apucarana; Rofas, em Jandaia do Sul, e Belman, em Califórnia. A participação do segmento no total do VAF industrial apresentou pequena elevação $(4,4 \%$ em 2000 e 4,7\% em 2004).

Cresce expressivamente o efetivo laboral do segmento - 498 empregados em 2000 e 1.297 em 2004, um acréscimo de 160,4\% na força de trabalho ocupada. As vantagens de aglomeração resultam na atração de mão-de-obra capacitada e fornecedores. O nível de instrução dos trabalhadores do segmento de uniformes e vestuário de segurança tem se elevado. Verificou-se uma ampliação significativa da participação dos trabalhadores que possuíam nível médio completo - 21,1\% do total do contingente em 2000 e $28,2 \%$ em 2004. As remunerações dos trabalhadores do segmento melhoraram substancialmente, com o percentual daqueles que auferem rendas entre 2 e 4 SMS tendo passado de $7,5 \%$ do total do empregados do segmento em 2000 para 38,6\% em 2004. Quanto à faixa etária do contingente laboral, a maioria estava na faixa entre 25 e 39 anos (cerca de 54\% para os anos 2000 e 2004), melhorando a participação dos mais velhos, com mais de 39 anos (de 8\% em 2000 a 13,7\% em 2004). A maioria é composta por homens (RAIS/MTE 2004). Questão de gênero novamente merece destaque, uma vez que os trabalhadores do sexo masculino, que tradicionalmente não sofrem discriminação de gênero, foram melhor sucedidos em obter ganhos salariais compatíveis com o grau de instrução.

São 48 empresas envolvidas nas atividades malharia, linhas, tapeçaria e outros têxteis sublinhando-se as empresas Estação da Malha (tecela- 
gem de malhas), Etikgil Etiquetas e Cruz Etiquetas, todas de Apucarana. A participação do segmento no VAF da indústria regional contou com significativa elevação, passando de 0,4\% em 2000 para 2,2\% em 2004. No segmento estamparia, texturização e outros acabamentos em tecidos há 12 empresas, destacando-se a empresa Paranatex (lavanderia e texturização).

Em 2004, a região detinha uma área plantada de 3 mil hectares de algodão, cuja produção foi de 6,6 mil toneladas (SEAB/DERAL 2004). Essa produção abastece as seis unidades fabris do segmento de têxtil de algodão da região, sendo elas: a tecelagem Têxtil Apucarana (sarja) e as empresas de beneficiamento e fiação de algodão: Novo Mutum, Paraguaçu Têxtil, São Judas e a Maclatex, em Apucarana; e a Algovale, em São João do Ivaí. A participação do segmento no total do VAF industrial da região declinou de 4,0\% em 2000 para 1,0\% em 2004.

\section{Região Londrina-Cambé}

A Região de Londrina-Cambé é constituída de 20 municípios, que ocupam uma área de $7.624 \mathrm{~km}^{2}$, assentada nas bacias hidrográficas dos rios Tibagi e Paranapanema. A projeção para 2005 do IBGE foi de aproximadamente 917 mil habitantes, dos quais 93,0\% estavam na área urbana. O número de estabelecimentos (496) no segmento têxtil-confecções e 16,2\% do emprego paranaense são destacados na tabela 3 .

No que se refere à formação de mão-de-obra com ênfase ao setor têxtilconfecções, além dos cursos profissionalizantes e de capacitação do Senai, há o curso superior de moda e estilismo na Universidade Estadual de Londrina (UEL), em Londrina. Importante aglomeração de indústrias de vestuário, a região conta com 362 confecções, destacando-se as empresas: Vest Hakme, Sonhart, Pura Mania, HKM, a WFS e a Z TEC, em Londrina; e Bella Vesti e D \& J, em Cambé. É expressivo o crescimento da participação do segmento no total do VAF industrial da região, passando de 2,9\% em 2000 para 3,2\% em 2004.

A mão-de-obra ocupada no setor do vestuário apresentou crescimento de 30,2\% no período 2000-2004, passando de 5.315 trabalhadores (11,8\% do total de trabalhadores industriais da região em 2000) para $6.920(12,2 \%$ em 2004). 
TABELA 3. NÚMERO DE ESTABELECIMENTOS, EMPREGADOS E PARTICIPAÇÃO NO VALOR ADICIONADO FISCAL (VAF) DO SETOR TEXXTIL-CONFECÇÕES - REGIÃO DE LONDRINA-CAMBÉ $-2000-2004$

\begin{tabular}{|c|c|c|c|c|c|c|c|c|}
\hline \multirow{3}{*}{ Segmento } & \multirow{2}{*}{\multicolumn{2}{|c|}{ Estabelecimentos }} & \multicolumn{4}{|c|}{ Empregados } & \multirow{2}{*}{\multicolumn{2}{|c|}{$\begin{array}{l}\text { Part. No vaf } \\
\text { regional (\%) }\end{array}$}} \\
\hline & & & \multicolumn{2}{|c|}{2000} & \multicolumn{2}{|c|}{2004} & & \\
\hline & 2000 & 2004 & abs. & $\%$ & abs. & $\%$ & 2000 & 2004 \\
\hline têxtil de algodão & 10 & 10 & 307 & 0,7 & 252 & 0,4 & 0,4 & 0,2 \\
\hline $\begin{array}{l}\text { têxtil de rami, seda e de outras fibras } \\
\text { naturais }\end{array}$ & 10 & 13 & 932 & 2,1 & 647 & 1,1 & 1,3 & 0,7 \\
\hline $\begin{array}{l}\text { malharia, linhas, tapeçaria e outros } \\
\text { têxteis }\end{array}$ & 46 & 60 & 833 & 1,9 & 839 & 1,5 & 0,3 & 0,2 \\
\hline vestuário & 278 & 362 & $5 \cdot 315$ & 11,8 & 6.920 & 12,2 & 2,9 & 3,2 \\
\hline $\begin{array}{l}\text { bonés, brindes e outros artefatos de } \\
\text { tecidos }\end{array}$ & 19 & 19 & 254 & 0,6 & 201 & 0,4 & 0,1 & 0,0 \\
\hline $\begin{array}{l}\text { estamparia, texturização e outros } \\
\text { acabamentos em tecidos }\end{array}$ & 9 & 13 & 224 & 0,5 & 260 & 0,5 & 0,2 & 0,2 \\
\hline uniformes e vestuário de segurança & 15 & 19 & 100 & 0,2 & 71 & 0,1 & 0,1 & 0,1 \\
\hline Total têxtil-confecções & 387 & 496 & 7.965 & 17,7 & 9.190 & 16,2 & 5,2 & 4,6 \\
\hline Demais segmentos & 1.886 & $\mathbf{2 . 3 1 0}$ & 37.132 & 82,3 & 47.690 & $\mathbf{8 3}, 9$ & 94,8 & 95,4 \\
\hline Total da região & 2.273 & 2.806 & 45.097 & 100,0 & 56.880 & 100,1 & 100,0 & 100,0 \\
\hline
\end{tabular}

FONTE: RAIS/MTE, SEFA. Elaboração das autoras.

A análise do perfil dos trabalhadores revelou que houve melhoria no nível de instrução, onde a participação dos trabalhadores com nível médio completo passou de $14,4 \%$ do contingente em 2000 para $26,1 \%$ em 2004 e a dos trabalhadores com nível superior completo dobrou, passando de $0,6 \%$ em 2000 para 1,2\% em 2004. Com relação aos salários dos trabalhadores, verificou-se que $72,3 \%$ em 2000 e $79,1 \%$ em 2004 auferiram menos de 2 SMs, e 22,5\% dos trabalhadores em 2000 e 17,4\% em 2004 recebiam entre 4 e 7 salários. O perfil etário sofreu poucas alterações: $45 \%$ do total de trabalhadores em 2000 e $46 \%$ em 2004 tinham entre 25 e 39 anos de idade, e $23,9 \%$ em 2000 e $25,3 \%$ em 2004, mais de 39 anos. No que se refere à composição e gênero dos trabalhadores, a participação das mulheres cresce de 50,9\% em 2000 para 85,7\% em 2004 (RAIS/MTE 2004).

O segmento de malharia, linhas, tapeçaria e outros têxteis da região é composto por 60 empresas, dentre as quais se destacam as empresas: Malui e Miami, de Cambé; Colorfio, Zapp, Costa Rica, Lyra \& Santana e Belamalha, de Londrina. É diminuta a participação do segmento no total do VAF da região (0,3\% em 2000 e $0,2 \%$ em 2004). Com o crescimento das indústrias de vestuário, o segmento de estamparia, texturização e outros acabamentos em tecidos que atuam em atividades complementares ao setor de confecções cresceu. São 13 empresas, com destaque para a lavanderia Clarear, em Londrina, e CLB Estamparia, em Cambé. São 10 estabelecimentos no segmento têxtil de algodão da região, distinguindo-se entre elas as unidades de Ibiporã e de Porecatu da Cooperativa Central de Algodão (COCEAL); também reúne a área de 
cotonicultura das cooperativas: Integrada, Corol e Coagel; a Texsul e a Têxtil Tiyo Umbertano, em Londrina; Texnort, em Cambé; a German e a Dorta, em Rolândia; e a unidade de Ibiporã da Cooperativa Agropecuária de Rolândia (COROL). Em que pese o considerável número de unidades produtivas, a contribuição do segmento na geração de empregos e renda industrial é inexpressiva.

Verificou-se no segmento têxtil de rami, seda e de outras fibras naturais 13 estabelecimentos. A participação do segmento no total do VAF da região declinou de 1,3\% em 2000 para 0,7\% em 2004. Em 2004, apenas dois municípios no Paraná cultivavam rami. Londrina era o maior produtor, com 339 hectares plantados, propiciando 757 toneladas do vegetal (o outro é Campina da Lagoa, na região de Campo Mourão-Goioerê). No beneficiamento de rami, havia três empresas operando no município de Londrina há mais de vinte anos: Carambeí (criada em 1965), com atividades de fiação de rami; a Itimura (1981) - com rami penteado e cabo de juta; e a Toyo Sen-I do Brasil (1973) - com rami penteado. Em Londrina, também se localizava uma unidade das maiores beneficiadoras de fios da seda do Brasil, a Bratac (1963). Além dessas, operavam no segmento a B R Têxtil, em Rolândia, e a Ibitex Seda, em Ibiporã. A participação do segmento no total de empregos da indústria regional declinou (2,1\% em 2000 para $1,1 \%$ em 2004), assim como a participação no total do VAF industrial (1,3\% em 2000 e $0,7 \%$ em 2004).

A crise da cotonicultura na década de 90 e a diversificação de atividades na região proporcionaram uma queda nos níveis de aglomeração e especialização do segmento têxtil de algodão na região em questão. Os demais segmentos têxteis permaneceram estáveis, não se verificando elevados investimentos, com pequena ampliação das plantas de rami, seda e outras fibras. Já no segmento de confecções, embora perdendo posições para outras regiões, apresenta-se com estrutura consolidada, com a presença de algumas grandes empresas com forte presença nacional.

\section{Região Maringá-Sarandi}

A Região de Maringá-Sarandi é formada por 29 municípios, ocupando uma área de 6,6 mil km², assentada na bacia hidrográfica do rio Pirapó. A projeção do IBGE para 2005 foi de uma população de aproximadamente 650 mil habitantes na região, dos quais $92,5 \%$ estavam na área urbana. O parque industrial da região Maringá-Sarandi conta com 699 confecções. A maioria foi instalada na década de 90, destacando-se as empresas MA Fallero, Corion e Recco, essas de Maringá, e a Multi Brasil, em Nova Esperança. A participação do segmento no total do VAF industrial da região reduziu-se, passando de $8,0 \%$ em 2000 para $7,3 \%$ em 2004. 
No que se refere à formação de mão-de-obra com ênfase ao setor têxtilconfecções, além dos cursos profissionalizantes e de capacitação do Senai, há o curso superior de moda e estilo na Universidade Estadual de Maringá (UEM), em Maringá, e graduação em Moda pela Faculdades Integradas de Maringá (CESUMAR).

Houve crescimento no número de trabalhadores ocupados no segmento de vestuário da região, com incremento de $43,8 \%$, passando de 6.302 empregadados $(23,4 \%$ do total de empregos industriais da região em 2000) para 9.251 (24,0\% em 2004) (tabela 4). Embora a maioria do contingente $(71,2 \%)$ em 2004 detivesse apenas grau de instrução até o fundamental completo, observou-se melhoria no nível educacional dos trabalhadores, principalmente no estrato que possuía nível médio completo, que passou $17,7 \%$ dos empregados do segmento em 2000 para $27,8 \%$ em 2004. No entanto, os salários não acompanharam a evolução da instrução do conjunto dos trabalhadores, crescendo a participação na faixa mais baixa, de até 2 SMs (66,4\% em 2000 e 78,6\% em 2004), verificando-se redução da participação daqueles que aferiam entre 2 e 4 SMs quase na mesma proporção (30,2\% em 2000 e 18,2\% em 2004). Em relação à faixa etária dos trabalhadores, houve um pequeno decréscimo da participação dos mais jovens (menores de 25 anos), passando de $39,0 \%$ do total de trabalhadores em 2000 para 37,3\% em 2004 na mesma proporção em que cresce a participação daqueles com idade entre 25 e 39 anos (40,6\% em 2000 para 42,0\% em 2004) (RAIS/MTE 2004).

TABELA 4. NÚMERO DE ESTABELECIMENTOS E EMPREGADOS; PARTICIPAÇÃO NO VALOR ADICIONADO FISCAL (VAF) DO SETOR TÊXTIL-CONFECÇÕES DA REGIÃO DE MARINGÁSARANDI - 2000/2004

\begin{tabular}{|c|c|c|c|c|c|c|c|c|}
\hline \multirow{3}{*}{ Segmento } & \multirow{2}{*}{\multicolumn{2}{|c|}{ Estabelecimentos }} & \multicolumn{4}{|c|}{ Empregados } & \multirow{2}{*}{\multicolumn{2}{|c|}{$\begin{array}{c}\text { Part. Vaf } \\
\text { regional (\%) }\end{array}$}} \\
\hline & & & \multicolumn{2}{|c|}{2000} & \multicolumn{2}{|c|}{2004} & & \\
\hline & 2000 & 2004 & abs. & $\%$ & abs. & $\%$ & 2000 & 2004 \\
\hline têxtil de algodão & 12 & 8 & 862 & 3,2 & 1.085 & 2,8 & 6,3 & 6,4 \\
\hline $\begin{array}{l}\text { têxtil de rami, seda e de outras fibras } \\
\text { naturais }\end{array}$ & 3 & 4 & 285 & 1,1 & 278 & 0,7 & 0,9 & 0,5 \\
\hline $\begin{array}{l}\text { malharia, linhas, tapeçaria e outros } \\
\text { têxteis }\end{array}$ & 42 & 63 & 470 & 1,7 & 590 & 1,5 & 0,5 & 0,3 \\
\hline vestuário & 377 & 699 & 6.302 & 23,4 & 9.251 & 24,0 & 8,0 & 7,3 \\
\hline $\begin{array}{l}\text { bonés, brindes e outros artefatos de } \\
\text { tecidos }\end{array}$ & 25 & 56 & 177 & 0,7 & 433 & 1,1 & 0,4 & 0,6 \\
\hline $\begin{array}{l}\text { estamparia, texturização e outros } \\
\text { acabamentos em tecidos }\end{array}$ & 5 & 21 & 41 & 0,2 & 258 & 0,7 & 0,0 & 0,4 \\
\hline uniformes e vestuário de segurança & 21 & 24 & 263 & 1,0 & 274 & 0,7 & 0,2 & 0,4 \\
\hline Total têxtil-confecções & 485 & 875 & 8.400 & 31,2 & 12.169 & $\mathbf{3 1 , 5}$ & 16,4 & 15,9 \\
\hline Demais segmentos & 1.407 & 1.814 & 18.558 & 68,9 & 26.450 & 68,5 & 83,6 & $\mathbf{8 4 , 1}$ \\
\hline Total da região & 1.892 & 2.689 & 26.958 & 100,0 & 38.619 & 100,0 & 100,0 & 100,0 \\
\hline
\end{tabular}

FONTE: RAIS/MTE, SEFA. Elaboração das autoras. 
Analisando o segmento do vestuário da região, Ipardes (2005c) identifica elevada heterogeneidade tecnológica e diversidade de produtos frente aos APL's de Cianorte e Apucarana. A gama de produtos ofertados inclui jeans, moda gestante, moda ginástica, moda social e lingerie. Há poucas empresas que adotam tecnologias avançadas, ao redor de 10, mas elas são responsáveis por $20 \%$ a $30 \%$ da produção de vestuário do município. A aquisição de matérias-primas é concentrada em São Paulo, Santa Catarina e Rio Grande do Sul, embora alguns itens sejam adquiridos no Paraná. A produção é voltada para o mercado nacional - principalmente São Paulo, Rio Grande do Sul e Mato Grosso do Sul. As exportações representam, no máximo, $5 \%$ de toda a comercialização do arranjo. O Projeto Condomínio Industrial, com área de $50 \mathrm{mil} \mathrm{m}^{2}$, abriga 20 empresas de confecções em Maringá, com área comum de logística mais a sede do sindicato. Outra iniciativa é o Programa Setorial Integrado - PSI, do qual participam cerca de 60 empresas de confecções da região, cuja proposta é a formação de um consórcio para exportação (Ipardes 2005c).

Já no segmento de malharia, linhas, tapeçaria e outros têxteis, são 59 empresas, empregando 590 pessoas, as quais representam $1,5 \%$ do total de empregos da região em 2004, destacando-se a empresa Gomes \& Cia, em Astorga, e a Aggi Têxtil, em Maringá.

Em 2004, registrou-se na região um total de 6,8 mil hectares plantados e produção de 11,8 mil toneladas de algodão, o que a torna a terceira maior produtora entre as regiões do Estado. Este fato afeta de maneira positiva o segmento industrial de têxtil de algodão, com parque fabril de oito empresas, sendo elas: a unidade da Cooperativa COCAMAR, Cooperfios e Esteves, em Maringá; a unidade de Mandaguari da Cooperativa de Cafeicultores de Mandaguari (COCARI); a Algodoeira Aurora, em Astorga; Padanosche Algodoeira e Carda Têxtil, em Colorado e a Fiação Mandaguaçu, em Mandaguaçu. A participação do segmento no total do VAF industrial da região permaneceu estável $(6,3 \%$ em 2000 e $6,4 \%$ em 2004). A mão-de-obra ocupada apresentou crescimento de $25,9 \%$, passando de 862 trabalhadores para 1.085, o que representou $3,2 \%$ e $2,8 \%$ no total de empregos industriais da região para os anos 2000 e 2004, respectivamente.

A produção de casulos de seda na região em 2004 registrou 1,9 mil toneladas, sustentada por uma área de 5,2 mil hectares de amoreira (que alimenta os bichos da seda) na região, com o destaque para o município de Nova Esperança (produção de 1,2 mil toneladas e 3 mil hectares plantados de amoreira) (SEAB/DERAL 2004). O segmento industrial de têxtil de rami, seda e de outras fibras naturais na região é composto de quatro estabelecimentos de secagem e fiação, destacando-se a Cooperativa COCAMAR (fiação de seda), em Maringá. 


\section{Região Umuarama-Cianorte}

A região de Umuarama-Cianorte é constituída por 32 municípios, ocupando uma área total de $14,4 \mathrm{mil} \mathrm{km}^{2}$, assentada sobre as bacias hidrográficas formadas, ao oeste, pelo Rio Paraná e, ao norte, pelo Ivaí. A projeção populacional da Região, segundo dados do IBGE para o ano de 2005, apresenta um número de aproximadamente 369 mil habitantes, dos quais 75,1\% concentrados na área urbana.

A região constituiu-se em importante aglomeração de confecções, congregando o maior número de empresas e mão-de-obra ocupada que atuam no setor no Paraná. Segundo Oliveira \& Maia (2004), a primeira confecção em Cianorte foi inaugurada em 1978 e a atividade, a partir deste período, teve uma expansão geométrica em termos da abertura de novos estabelecimentos, com 238 confecções em 1995; 672 em 2002, chegando a 712 empresas em 2004. Deve-se considerar a existência de cerca de 1.200 empresas domiciliares informais, segundo levantamento da Prefeitura Municipal de Cianorte em 2003, que compõem o segmento. Dentre as empresas integrantes do APL destacam-se a Be Eight, Morena Rosa, Lúcia Figueredo e For Boys (Cianorte); Rouvaplas (Japurá); Storti (Altônia) e Retook (Umuarama). A participação do segmento no VAF da indústria da região apresentou queda, passando de $14,4 \% \mathrm{em}$ 2000 para $13,4 \%$ em 2004. O segmento ocupava em 2004 um contingente de 9.562 empregados, que representavam $35,0 \%$ do total dos trabalhadores industriais da região, o que significa a maior representação deste segmento em termos regionais deste segmento.

A mão-de-obra ocupada no setor do vestuário da região apresentou crescimento de 72,6\% no período 2000-2004, passando de 5.539 trabalhadores para 9.562 em 2004. A análise do perfil dos trabalhadores observou que, embora a maioria possuísse até o nível fundamental completo $(84,6 \%$ em 2000 e $71,6 \%$ em 2004), houve melhoria no nível de instrução, com crescimento da participação dos trabalhadores com o nível médio completo passando de 14,8\% do contingente em 2000 para 27,7\% em 2004. Em relação aos salários: a) a maioria auferia até 2 SMs - 70,4\% dos trabalhadores em 2000 e, com o aumento do número de empregados, esta participação atingiu $84,2 \%$ em 2004; e b) houve uma redução na faixa 4 a 7 salários - 26,8\% dos trabalhadores em 2000 e 13,8\% em 2004. O perfil etário sofreu poucas alterações: em torno de $40 \%$ nos dois anos analisados com idade até 24 anos; pequeno decréscimo da participação daqueles com idade entre 25 e 39, passando de 44,0\% do total de trabalhadores em 2000 para 42,5\% em 2004; e, com mais de 39 anos representou em torno de 17,0\% do total, nos anos 2000/2004. Observou-se também um acréscimo expressivo da participação feminina no segmento, visto que em 2000 45,8\% da mão-de-obra local era 
composta de mulheres, a qual foi passou a representar, em 2004, 75,8\% do total da mão-de-obra da região (RAIS/MTE 2004).

TABELA 5. TOTAL DE ESTABELECIMENTOS, DE EMPREGADOS E PARTICIPAÇÃO NO VALOR ADICIONADO FISCAL (VAF) DO SETOR TÊXTIL-CONFECÇÕES - REGIÃO DE UMUARAMACIANORTE, 2000-2004

\begin{tabular}{|c|c|c|c|c|c|c|c|c|}
\hline \multirow{3}{*}{ Segmento } & \multirow{2}{*}{\multicolumn{2}{|c|}{$\begin{array}{c}\text { No. } \\
\text { Estabelecimentos }\end{array}$}} & \multicolumn{4}{|c|}{ Empregados } & \multirow{2}{*}{\multicolumn{2}{|c|}{$\begin{array}{r}\text { Part. No vaf } \\
\text { da região }(\%)\end{array}$}} \\
\hline & & & \multicolumn{2}{|c|}{2000} & \multicolumn{2}{|c|}{2004} & & \\
\hline & 2000 & 2004 & Abs. & $\%$ & Abs. & $\%$ & 2000 & 2004 \\
\hline têxtil de algodão & 13 & 8 & 172 & 1,1 & 57 & 0,2 & 1,1 & 1,2 \\
\hline têxtil de rami, seda e de outras fibras naturais & 3 & - & 20 & 0,1 & - & - & 0,0 & - \\
\hline malharia, linhas, tapeçaria e outros têxteis & 29 & 24 & 466 & 3,1 & 375 & 1,4 & 0,5 & 0,2 \\
\hline vestuário & 426 & 712 & 5.539 & 36,5 & 9.562 & 35,0 & 14,4 & 13,4 \\
\hline bonés, brindes e outros artefatos de tecidos & 13 & 23 & 164 & 1,1 & 488 & 1,8 & 0,1 & 0,3 \\
\hline $\begin{array}{l}\text { estamparia, texturização e outros acabamentos } \\
\text { em tecidos }\end{array}$ & 2 & 15 & - & - & 131 & 0,5 & 0,9 & 1,2 \\
\hline uniformes e vestuário de segurança & 2 & 2 & - & - & 3 & 0,0 & 0,0 & 0,0 \\
\hline Total setor têxtil-confecções & 488 & 784 & 6.361 & 41,9 & 10.616 & 38,9 & 17,1 & 16,2 \\
\hline Demais segmentos & 746 & 866 & 8.802 & 58,1 & 16.705 & 61,1 & 82,9 & 83,8 \\
\hline Total da região & 1.234 & 1.650 & 15.163 & 100,0 & 27.321 & 100,0 & 100,0 & 100,0 \\
\hline
\end{tabular}

FONTE: RAIS/MTE e SEFA. Elaboração das autoras.

No segmento de malharia, linhas, tapeçaria e outros têxteis, são 24 estabelecimentos, capitaneados pelas empresas Umed (gazes hospitalares) e Umatex (panos de limpeza marca Limpermil), ambas em Umuarama, e Barbantes Cianorte, em Cianorte.

Segundo Campos (2004), para oferecer ao mercado consumidor produtos diferenciados, as confecções de jeans estão investindo em novas tecnologias. Entre elas está a técnica de lavanderia, com uma gama de opções em tratamentos químicos e a laser nos processos de tingir, lavar, lixar, amassar, desbotar, que produzem peças exclusivas, fashion e diferenciadas, o que favorece outro segmento da cadeia que é o de estamparia, texturização e outros acabamentos em tecidos, com 15 empresas instaladas na região, destacando-se as lavanderias Lavinort e Adriana, em Cianorte. O segmento representava 0,9\% do VAF industrial da região em 2000 e 1,2\% em 2004 (ver tabela 5).

O principal município produtor de confecções da região é Cianorte, conhecida como "A Capital do Vestuário". Considerado um grande aglomerado produtor de moda do sul do País, ele produziu-se neste APL mais de cinco milhões de peças/mês, as quais são comercializadas em cinco Shoppings Atacadistas e na Rua da Moda. Estes Shoppings abrigaram a produção de um número superior a 400 lojas das fábricas. A Expovest, feira de exposição, tem se realizado em duas edições anuais 
no município e também tem atraído compradores de todo o território nacional.

Dentre os inúmeros pontos de destaque do aglomerado podem ser relacionados a existência de Cooperativa de Crédito (Sicoob); o arranjo institucional totalmente centrado na confecção; o modelo comercial de sucesso da ASAMODA (copiado por outros arranjos do país), e a capacidade de crescimento comercial por meio do uso de guias de moda. Outros aspectos positivos do aglomerado são: o marketing, o espírito associativista local entre produtores e lojistas; o transbordamento das atividades que contribuem para o desenvolvimento dos municípios da região, além da perspectiva e das negociações em torno da formação do Consórcio de Exportação.

Compondo a estrutura de ensino com ênfase ao setor têxtil-confecções, destacam-se os cursos de Moda da unidade da Universidade Estadual de Maringá (UEM) em Cianorte e da Universidade Paranaense (Unipar), ambas nos níveis universitários, e a Escola-Fábrica, mantida pelo SENAI no nível técnico e profissionalizante.

Em 2004, a região possuía a maior área plantada de algodão do Estado, com 11 mil hectares, que geraram produção de 19,5 mil toneladas, potencial fornecedor para o setor de têxtil de algodão, com oito estabelecimentos atuando no beneficiamento e fiação de algodão, com destaque para as empresas NKR, Soalgo e Algoeste, todas em Umuarama. O segmento apresentou uma participação estável para os anos 2000-2004 no total do VAF da região, representando $1,1 \%$ e $1,2 \%$, respectivamente.

A região detinha em 2004 a segunda maior criação de bicho-da-seda do Estado, gerando 2 mil toneladas de casulos, com a presença de uma unidade de secagem do bicho-seda-da empresa Kanebo Silk do Brasil, em Umuarama.

\subsection{Outras aglomerações especializadas}

\section{Região Francisco Beltrão-Pato Branco}

A região de Pato Branco-Francisco Beltrão é constituída por 37 municípios, que ocupam área total de $11,5 \mathrm{mil} \mathrm{km}^{2}$, assentada na bacia hidrográfica do rio Iguaçu. A projeção do IBGE para 2005 é que sua população seja de aproximadamente 469 mil habitantes, dos quais 59,9\% encontravam-se na área urbana.

A tabela 6 apresenta os indicadores da região de Francisco Beltrão-Pato Branco e destacam-se as empresas do vestuário e de malharias, sua capacidade de geração de emprego e a participação no VAF da região. O 
segmento de vestuário conta com 169 estabelecimentos na região. Destacam-se as empresas Krindges (Ampére), com produção aproximada de 220 mil peças por mês, predominantemente de roupas masculinas (social e esportiva); a Ermínia Latreille (jeans) (Dois Vizinhos); a Confecções Raffer (Francisco Beltrão), e a TM Indústria (Santo Antônio do Sudoeste). A participação do segmento no VAF da indústria da região cai expressivamente, passando de 10,2\% em 2000 para 8,0\% em 2004.

A análise do perfil da mão-de-obra ocupada do segmento do vestuário da região revelou uma expansão positiva de $61,8 \%$ no total do efetivo, passando de 3.270 empregados em 2000 (representando $21,6 \%$ do emprego industrial regional) para 5.292 em 2004 (24,6\%). Quanto ao grau de instrução, verificou-se o aumento da participação dos trabalhadores com nível médio, que passou de $15,1 \%$ do total do contingente em 2000 para 27,3\% em 2004. No entanto, esta evolução não é acompanhada por melhorias salariais, visto que os rendimentos da maioria (79,9\% em 2000 e 95,8\% em 2004) está na faixa de até 2 SMs, com declínio nas faixas salariais mais altas. Verificou-se o aumento da participação dos trabalhadores mais jovens, com idade 24 anos $(38,4 \%$ em 2000 e 41,2\% em 2004), na mesma proporção em que se reduz a participação daqueles que possuíam entre 25-39 anos (45,0\% em 2000 e $42,6 \%$ em 2004). Apesar de reduzir um pouco a sua participação no total, a maioria do contingente é do sexo feminino $(85,1 \%$ em 2000 e $78,8 \%$ em 2004) (RAIS/MTE 2004). Em relação às demais regiões especializadas no setor têxtil-confecções do Estado, a região de Francisco Beltrão-Pato Branco apresentou o maior incremento de postos de trabalho. Este novo contingente de trabalhadores compõe-se preponderantemente de mulheres jovens, com remunerações abaixo da média de seus colegas já colocados.

Quinze empresas de sete municípios da região estão integradas ao Programa de Competitividade para a Indústria de Confecção do Sudoeste, desenvolvido pelo Sebrae. As confeccionistas contam com ampla estrutura de formação e capacitação da mão-de-obra, entre elas: escolas de qualificação de mão-de-obra nos municípios de Pato Branco, Francisco Beltrão, Dois Vizinhos, Santo Antônio do Sudoeste, Chopinzinho, Barracão, Planalto, Ampére, Santa Izabel do Oeste, Nova Prata do Iguaçu e Salto do Lontra; curso de Tecnologia do Vestuário na União de Ensino do Sudoeste do Paraná (Unisep), em Dois Vizinhos; curso de pós-graduação em Design da Moda na Faculdade de Pato Branco (Fadep); curso Técnico em Confecções e técnico de Estilismo no Senai (pós-médio) em Pato Branco e curso técnico em Confecção (pós-médio) em Francisco Beltrão. Em fevereiro de 2006, foi inaugurado o Centro de Treinamento e Desenvolvimento do Vestuário em Francisco Beltrão e está em construção um minicentro de treinamento para Ampére (Mostra 2004). 
OLIVEIRA, M. A. et al. O setor têxtil-confecções do Paraná...

TABELA 6. NÚMERO DE ESTABELECIMENTOS, EMPREGADOS E PARTICIPAÇÃO NO VALOR ADICIONADO FISCAL (VAF) DO SETOR TÊXTIL-CONFECÇÕES DA REGIÃO DE FRANCISCO BELTRÃO-PATO BRANCO - 2000-2004

\begin{tabular}{|c|c|c|c|c|c|c|c|c|}
\hline \multirow{3}{*}{ Segmento } & \multirow{2}{*}{\multicolumn{2}{|c|}{ Estabelecimentos }} & \multicolumn{4}{|c|}{ Empregados } & \multirow{2}{*}{\multicolumn{2}{|c|}{$\begin{array}{l}\text { Part. No vaf } \\
\text { regional (\%) }\end{array}$}} \\
\hline & & & \multicolumn{2}{|c|}{2000} & \multicolumn{2}{|c|}{2004} & & \\
\hline & 2000 & 2004 & Abs. & $\%$ & Abs. & $\%$ & 2000 & 2004 \\
\hline têxtil de algodão & 1 & 1 & - & - & - & - & 0,0 & 0,0 \\
\hline $\begin{array}{l}\text { malharia, linhas, tapeçaria e } \\
\text { outros têxteis }\end{array}$ & 30 & 26 & 219 & 1,5 & 289 & 1,3 & 0,6 & 0,1 \\
\hline vestuário & 128 & 169 & 3.270 & 21,6 & 5.292 & 24,6 & 10,2 & 8,0 \\
\hline $\begin{array}{l}\text { bonés, brindes e outros artefatos } \\
\text { de tecidos }\end{array}$ & 6 & 15 & 43 & 0,3 & 80 & 0,4 & 0,0 & 0,0 \\
\hline $\begin{array}{l}\text { estamparia, texturização e outros } \\
\text { acabamentos em tecidos }\end{array}$ & 1 & 16 & 3 & 0,0 & 22 & 0,1 & 0,0 & 0,5 \\
\hline $\begin{array}{l}\text { uniformes e vestuário de } \\
\text { segurança }\end{array}$ & 2 & 5 & 4 & 0,0 & 58 & 0,3 & 0,0 & 0,1 \\
\hline Total setor têxtil-confecções & 168 & 232 & 3.539 & 23,4 & 5.741 & 26,6 & 10,8 & 8,7 \\
\hline Demais segmentos & 1.082 & 1.316 & 11.580 & 76,6 & 15.815 & 73,4 & 89,2 & 91,3 \\
\hline Total da região & 1.250 & 1.548 & 15.119 & 100,0 & 21.556 & 100,0 & 100,0 & 100,0 \\
\hline
\end{tabular}

FONTE: RAIS/MTE, SEFA. Elaboração das autoras.

Segundo dados do Sindicato das Indústrias do Vestuário do Sudoeste do Paraná (SINVESPAR), as empresas da região têm uma produção total estimada em 16 milhões de peças/ano. Algumas dessas empresas trabalham com marcas reconhecidas nacionalmente, disputando mercado com as mais tradicionais e ocupam os primeiros lugares na lista das empresas que mais faturam na região. No segmento de malharia, linhas, tapeçaria e outros têxteis há 26 estabelecimentos industriais atuantes, capitaneadas pelas empresas Malharia Kenusa e Confecções Helter (moda bebê, em Francisco Beltrão) e Winter (Dois Vizinhos).

\section{Região Campo Mourão-Goioerê}

A Região de Campo Mourão-Goioerê é composta por 22 municípios,

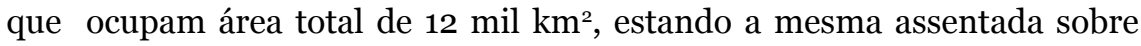
as bacias hidrográficas dos rios Ivaí e Piquiri. Pela projeção do IBGE para 2005, a região possuía aproximadamente 321 mil habitantes, dos quais $72,6 \%$ concentrados na área urbana.

Em relação à formação de mão-de-obra, a Universidade Estadual de Maringá mantêm no município de Goioerê o curso de Engenharia da Produção Têxtil.

Em 2004, a região se posicionava, dentre as demais regiões do Estado, como segunda na produção de algodão, com 7,4 mil hectares plantados, gerando 16 mil toneladas, com destaque para os municípios de Janiópolis e Moreira Sales, onde se concentra a maior parte da produ- 
ção. Esta produção é potencial fornecedora das 15 empresas componentes do segmento de têxtil de algodão da região. Sublinham-se as empresas: Cooperativa Mourãoense (Coamo), em Campo Mourão; Cooperativa Agropecuária Goioerê (Coagel); a unidade da Cooperativa Integrada, em Goioerê; as unidades de Campo Mourão e Luziânia da empresa Algolim; e Cooperativa Agropecuária União (Coagru), em Ubiratã. A participação do segmento no VAF industrial declinou de 21,5\%, em 2000, para $18,3 \%$, em 2004 (tabela 7).
TABELA 7. NÚMERO DE ESTABELECIMENTOS, EMPREGADOS E PARTICIPAÇÃO NO VALOR ADICIONADO FISCAL (VAF) DO SETOR TÊXTIL-CONFECÇÕES DA REGIÃO DE CAMPO MOURÃO- GOIOERE - 2000-2004

\begin{tabular}{|c|c|c|c|c|c|c|c|c|}
\hline \multirow{3}{*}{ Segmento } & \multirow{2}{*}{\multicolumn{2}{|c|}{ Estabelecimentos }} & \multicolumn{4}{|c|}{ Empregados } & \multirow{2}{*}{\multicolumn{2}{|c|}{$\begin{array}{l}\text { Part. No vaf } \\
\text { regional (\%) }\end{array}$}} \\
\hline & & & \multicolumn{2}{|c|}{2000} & \multicolumn{2}{|c|}{2004} & & \\
\hline & 2000 & 2004 & Abs. & $\%$ & Abs. & $\%$ & 2000 & 2004 \\
\hline têxtil de algodão & 11 & 15 & 318 & 5,5 & 347 & 3,6 & 21,5 & 18,3 \\
\hline $\begin{array}{l}\text { têxtil de rami, seda e de outras } \\
\text { fibras naturais }\end{array}$ & 1 & 1 & - & - & 6 & 0,1 & 0,0 & - \\
\hline $\begin{array}{l}\text { malharia, linhas, tapeçaria e outros } \\
\text { têxteis }\end{array}$ & 10 & 15 & 78 & 1,3 & 117 & 1,2 & 1,3 & 0,4 \\
\hline vestuário & 67 & 109 & 1.222 & 20,9 & 1.644 & 17,2 & 4,3 & 4,1 \\
\hline $\begin{array}{l}\text { bonés, brindes e outros artefatos } \\
\text { de tecidos }\end{array}$ & 7 & 12 & 147 & 2,5 & 190 & 2,0 & 0,2 & 0,4 \\
\hline $\begin{array}{l}\text { estamparia, texturização e outros } \\
\text { acabamentos em tecidos }\end{array}$ & 2 & 10 & 42 & 0,7 & 71 & 0,7 & 0,4 & 0,7 \\
\hline $\begin{array}{l}\text { uniformes e vestuário de } \\
\text { segurança }\end{array}$ & 1 & 4 & 54 & 0,9 & 102 & 1,1 & 0,2 & 0,1 \\
\hline Total setor têxtil-confecções & 99 & 166 & 1.861 & 31,9 & 2.477 & 25,8 & 27,8 & 24,0 \\
\hline Demais Segmentos & 529 & 538 & 3.979 & 68,2 & 7.108 & 74,2 & 72,2 & 76,0 \\
\hline Total da região & 628 & 704 & 5.840 & 100,0 & 9.585 & 100,0 & 100,0 & 100,0 \\
\hline
\end{tabular}

FONTE: RAIS/MTE, SEFA. Elaborado pelas autoras.

A atividade algodoeira na região vem se recuperando gradativamente através de algumas iniciativas locais, como o Programa de Incentivo à Cotonicultura, promovido pela Emater, Secretaria da Agricultura e prefeituras da região, com participação da Cooperativa Coagel. O programa cadastrou 149 pequenos agricultores rurais se constitui na distribuição de kits contendo um saco de semente tratada de algodão e $500 \mathrm{~kg}$ de adubo químico. Para o município de Goioerê foram destinados 200 kits, sendo que cada produtor teve direito a receber até dois kits (Emater 2004).

O município de Campina da Lagoa abriga 200 hectares da cultura do rami, produzindo 440 toneladas do vegetal. 


\section{Região Cornélio Procópio-Bandeirantes}

A Região de Cornélio Procópio-Bandeirantes é composta por 20 municípios, ocupando uma área total de $6,3 \mathrm{mil} \mathrm{km}^{2}$, assentada sobre as bacias hidrográficas dos rios Paranapanema e Cinzas. A projeção populacional do IBGE para 2005 foi de aproximadamente 222 mil habitantes na região, dos quais $35,8 \%$ residentes na área urbana.

Segundo dados do SEAB/DERAL de 2004, a região abrigava uma área plantada de 3,5 mil hectares de algodão, que geraram 8,8 mil toneladas do vegetal, potencial abastecedor do segmento têxtil de algodão, que conta com 10 unidades fabris. Destaca-se a Cooperativa Integrada, em Assaí, que atua na região em conjunto com a Cooperativa Central de Algodão (Coceal). Esta unidade apresentou, em 2004, produção de aproximadamente 500 toneladas por mês de fios de algodão. O segmento conta também com as empresas: Algodoeira Ouro Branco, em Jataizinho; Algodoeira Taji e a Beneficiadora Morita, em Santa Amélia; a Koppin, em Bandeirantes; e a Imperial Fibras, em Uraí. A participação do segmento no VAF industrial da região apresentou violenta queda, passando de $17,8 \%$ em 2000 para 8,6\% em 2004. A mão-de-obra lotada no segmento mantém-se praticamente estável, com aproximadamente 370 trabalhadores.

O segmento têxtil de rami, seda e de outras fibras naturais está presente em Cornélio Procópio através da indústria japonesa Kanebo Silk (secagem e fiação de seda), criada em 1973, que exporta quase toda produção. A participação do segmento no VAF industrial da região elevou-se, passando de 2,2\% em 2000 para 6,1\% em 2004. No que tange à mão-deobra ocupada, apresenta perda de postos de trabalho, com 897 empregados em 2000 ( $17,3 \%$ dos trabalhadores industriais da região) e 855 em $2004(13,4 \%)$.

\section{Aglomeração municipal de Terra Roxa - moda bebê}

Terra Roxa é conhecida nacionalmente como "Capital Nacional das Confecções de Moda Bebê" e sua produção atende o mercado infantil até um ano de idade. Em 2004, segundo dados do MTE/RAIS, o segmento do vestuário do município abrigava uma mão-de-obra de 720 empregados, sendo 63,0\% deles nas empresas de moda bebê. A atividade é responsável por aproximadamente $30 \%$ da economia do município, com faturamento mensal em torno de R $\$ 1,5$ milhão e produção estimada em $200 \mathrm{mil} \mathrm{peças/mês,} \mathrm{cerca} \mathrm{de} \mathrm{2,5} \mathrm{milhões} \mathrm{de} \mathrm{peças/ano} \mathrm{(PDI} \mathrm{2005).}$ Pelas informações obtidas na Secretaria de Finanças de Terra Roxa, existem 48 empresas ligadas às confecções, sendo que a grande maioria das empresas emprega até 19 pessoas, ou seja, são microempresas e distribuem seus produtos em todo o território nacional por meio de repre- 
sentantes comerciais. Do ponto de vista institucional, o arranjo está ancorado no Comitê Gestor do APL, que conforma a governança local, apoiado por instituições externas, destacando-se a atuação do Sebrae.

\section{Aglomeração municipal de Imbituva - malhas retilíneas}

O APL de Imbituva é composto, atualmente, segundo a Associação das Malharias de Imbituva (Imbitumalhas), por 44 empresas formais de micro e de pequeno portes, que têm por especialização a produção de malhas. Em termos de emprego, a RAIS mostra a presença de 139 trabalhadores com vínculo formal e um número desconhecido de trabalhadores domiciliares. A produção local é comercializada predominantemente nos estados do Paraná, Santa Catarina, São Paulo e, em menor escala, no Rio Grande do Sul. Os principais canais de comercialização são as lojas de fábricas e a Feira de Malhas de Imbituva (FEMAI), com vendas no atacado e no varejo. Recentemente, algumas empresas vêm adotando (como estratégia de ampliação de mercado e planejamento da produção) a comercialização por meio de representação comercial (Ipardes 2005c).

Uma particularidade do APL refere-se à predominância absoluta da gestão empresarial familiar, a qual proporciona a facilitação de relações de cooperação e de interação entre os atores locais. A intermediadora formal destas relações e também a instituição mais importante do segmento é a Imbitumalhas, criada em 1978, a qual vem, nos últimos anos, conseguindo maior mobilização dos empresários, coordenando ações coletivas estruturantes da atividade e consolidando uma identidade local.

\section{Considerações finais}

Utilizando-se da metodologia proposta neste trabalho, o quadro 3 elenca e classifica os elementos mais importantes e característicos de cada aglomeração especializada que pode ser sumariamente assim analisada:

O segmento têxtil de algodão compreende as atividades agrícolas, de beneficiamento, fiação e tecelagem de algodão e conta com várias beneficiadoras pulverizadas pelo estado e três tecelagens. Apesar das iniciativas públicas e privadas para reabilitação do setor, os dados de 2000-2004 deste segmento apresentam redução acentuada da produção, geração de empregos e renda agrícola e industrial em função da crise da cotonicultura paranaense. O setor têxtil de rami, seda e de outras fibras naturais apresentou poucos investimentos e avanços na atividade produtiva, denotando tendências à estagnação. Esta atividade 
produtiva continuou sendo realizada nas plantas existentes no início do período analisado, identificando-se algumas pequenas oscilações positivas na produção primária.

Quanto ao segmento de malharias, observou-se expansão no segmento, especialmente no ramo de malharia, linhas, tapeçaria e outros têxteis, merecendo destaque a maior participação nas atividades de artefatos têxteis (barbantes, cordas, sacarias) e algumas tecelagens de malhas (circulares). No ramo de tricotagem (malha retilínea), destacou-se a aglomeração do município de Imbituva, a qual concentra o maior número de malharias do Estado.

Por outro lado, os segmentos relacionados às confecções apresentaram um ritmo acelerado de expansão no Estado, particularmente no chamado "Corredor da Moda". Contudo, a região sudoeste do Estado também revelou índices significativos de crescimento, principalmente em termos de emprego.

Analisado o perfil da mão-de-obra alocada, no grupo têxtil, a maioria é formada por homens e apresenta um percentual mais alto de instruídos e mais idosos que o grupo de confecções.

Em relação ao perfil laboral do grupo confecções, na questão de gênero verificou-se que, em função do desemprego generalizado na década de 1990, houve um aumento expressivo da participação masculina em alguns segmentos tradicionalmente femininos, entre eles o de confecções. No período 2000-2004, com a recuperação econômica e criação de empregos, inicia-se o retorno deste contingente para as atividades tradicionais masculinas. Este fenômeno diferencia-se em cada aglomeração do Estado. Nas regiões mais dinâmicas e diversificadas economicamente (Londrina e Maringá), onde há alternativas para a mão-de-obra masculina, a participação dos homens no setor declina acentuadamente; por outro lado, nas regiões com a presença de poucos segmentos industriais (Cianorte, Apucarana) esta redução é menos acentuada e, em algumas funções, há crescimento da participação masculina (principalmente jovem). De maneira geral, os novos postos de trabalho criados no período 2000/2004 foram ocupados por mulheres, com idade entre 25 e 39 anos, auferindo até 2 SMs para funções em geral de costureira e auxiliar de costura.

Outra constatação na análise do mercado de trabalho no setor é que a melhoria da escolaridade não resulta espontaneamente em ganhos salariais. Este comportamento se dá em função da tradição do setor de valorizar mais a experiência do trabalhador do que seu grau de instrução. No caso das mulheres, devido à discriminação do gênero, o hiato entre grau de instrução e salários é ainda mais acentuado. Em termos regionais a região de Apucarana-Ivaiporã apresentou níveis salariais médios mais elevados. 
A análise do comportamento do setor têxtil-confecções no "Corredor da Moda" permite inferir que as aglomerações analisadas seriam beneficiadas se houvesse um tratamento conjunto das demandas do setor neste eixo. A proposição que parece cabível é no sentido de se tratar e planejar este eixo como um sistema intitulado de "Corredor da Moda" do nortenoroeste do Paraná, ação que seria favorecida em função da proximidade física entre as aglomerações e pelas especificidades de seus produtos.

Neste eixo produtivo, Cianorte e Apucarana são aglomerados que estão atraindo um número maior de estabelecimentos pequenos que operam na fase final da cadeia produtiva. Em contrapartida, Londrina e Maringá, mais diversificadas, têm atraído grandes fornecedores da área têxtil. Cianorte, Apucarana e Maringá possuem maiores níveis de especialização, correspondendo a alguns dos principais pólos do vestuário brasileiro. As aglomerações industriais de Cianorte e de Apucarana caracterizam-se como arranjos produtivos organizados, pois ambas possuem governança e instituições fortes. Destaca-se a presença, em Apucarana, de uma grande tecelagem, fator que já beneficia a cadeia têxtil-confecções do "Corredor da Moda".

A partir da evolução (positiva ou negativa) do número de plantas industriais e/ou empresas correlatas - fator que contribui para o maior adensamento da cadeia -, caracterizou-se a estrutura produtiva das regiões especializadas nas tipologias: estável (com pouca ou nenhuma alteração na sua malha produtiva), estagnada (sem crescimento em plantas), em expansão (com crescimento acentuado no número de empresas, e em retração (quando há perda acentuada de plantas produtivas). A indústria têxtil de seda mostrou-se estável no tempo, a indústria têxtil de algodão apresentou retração (exceto sudoeste), e verificou-se o crescimento dos demais segmentos analisados na maioria das regiões especializadas, contribuindo para o desenvolvimento regional.

A aglomeração da região de Francisco Beltrão-Pato Branco, especializada em moda masculina, apresenta forte articulação interinstitucional e realiza esforço para obter uma mão-de-obra mais qualificada. Terra Roxa destaca-se pela especialização em moda bebê e orienta suas ações para se capacitar financeiramente para aquisição de máquinas de bordar e na divulgação nacional de suas marcas.

O setor têxtil-confecções é de extrema importância no contexto econômico e social do Estado. Logo, faz-se necessária a gestão de um projeto único para o setor que considere os diferentes estágios de desenvolvimento das aglomerações analisadas. Vale salientar a estratégica atuação da Rede de APLs Paraná, a qual deve atuar como instituição-ponte na medida em que congrega as empresas, as instituições públicas e parapúblicas no desenvolvimento de ações globais estruturantes para os APLs do Paraná. 
OLIVEIRA, M. A. et al. O setor têxtil-confecções do Paraná...

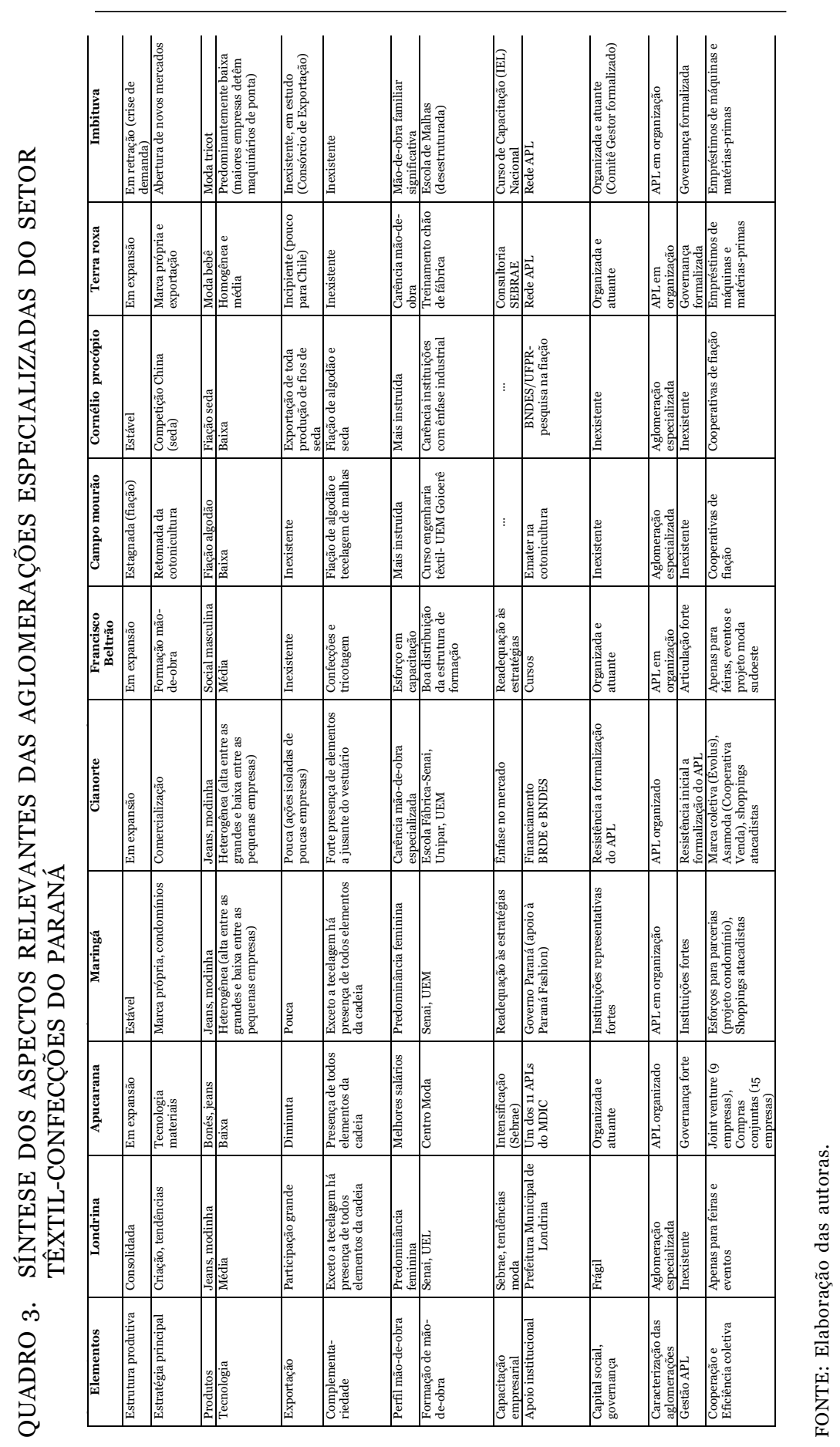




\section{Referências}

ALBAGLI, S. \& BRITO, J. (orgs) (2003). Glossário de arranjos e sistemas produtivos $e$ inovativos locais. In LASTRES, H. M. \& CASSIOLATO, J. E. (coords). RedeSist: fev. 2003.

ARBEX, M. A. (2005). Aglomeração industrial de empresas do vestuário no município de Londrina. Londrina: dissertação de mestrado. Programa de Mestrado PPA/UEM/UEL.

CAMPOS, A C. (2004). Arranjos produtivos no Estado do Paraná: o caso do município de Cianorte. Curitiba: tese de doutorado, UFPR-PPGDE.

CAMPOS, R \& CÁRIO, S. \& NICOLAU, J. (2000). Arranjos e sistemas produtivos locais e as novas políticas de desenvolvimento industrial e tecnológico. Nota Técnica 20. Rio de Janeiro: IE-UFRJ, dezembro.

CASSIOLATO, J. E. \& SZAPIRO, M. (2003). "Uma caracterização de arranjos produtivos locais de micro e pequenas empresas.” In LASTRES, H. \& CASSIOLATO, J. \& MACIEL, M. (orgs). Pequena empresa: cooperação e desenvolvimento local. Rio de Janeiro: Relume Dumará.

CASSIOLATO, J. E. \& LASTRES, H. M. (2001). "Aglomerações, cadeias e sistemas produtivos e de inovações." Revista Brasileira de Competitividade $1(1)$.

CASSIOLATO, J. E. \& LASTRES, H. M. (2003). "O foco em arranjos produtivos e inovativos locais de micro e pequenas empresas.” In LASTRES, H. \& CASSIOLATO, J. \& MACIEL, M. (orgs). Pequena empresa: cooperação e desenvolvimento local. Rio de Janeiro: Relume Dumara.

EDQUIST, C. (1997). Systems of innovation: technologies, institutions and organizations. London \& Washington: Pinter.

EDQUIST, C. (2001). "The systems of innovation approach and innovation policy: an account of the state of the art." DRUID Conference, Aalborg, junho.

EMATER (2004). "Emater cadastrou 149 agricultores." URL: http:// www.goionews.com.br. Acesso em: 10 de outubro de 2004.

FIEP (2005). URL: http://www.fiepr.org.br/noticias. Acesso em: 19/o8/2005.

FREEMAN, C. (1995). "The national system of innovation in historical perspective." Cambridge Journal of Economics 19(1): 5-24.

GORINI, A. P. (2000). "Panorama do setor têxtil no Brasil e no mundo: reestruturação e perspectivas.” BNDES Setorial 12: 17-50.

GUERIN, M. (2004). “Bicho-da-seda reage.” Folha de Londrina, 07/08/2004, Folha Rural: 3 .

HAGUENAUER, L. \& PROCHNIK, V. (2000). Identificação de cadeias produtivas e oportunidades de investimento no Nordeste. Fortaleza: Banco do Nordeste.

HUMPHREY, J. \& SCHMITZ, H. (1998). "Trust and inter-firm relations in developing and transition economics." The Journal of Development Studies $34(4)$. 
IPARDES (2003). Arranjos produtivos locais e o novo padrão de especialização regional da indústria paranaense na década de 9o. Curitiba: Ipardes.

IPARDES (2005). Projeto identificação, caracterização, construção de tipologia e apoio na formulação de políticas para os Arranjos Produtivos Locais (APLs) do Estado do Paraná etapa 3. Curitiba: Ipardes.

IPARDES (2006). Censo industrial do arranjo produtivo local de confecções de bonés de Apucarana no Estado do Paraná. Curitiba: Ipardes.

KUPFER, D. (1998). Trajetórias de reestruturação da indústria brasileira após a abertura e a estabilização. Rio de Janeiro: tese de doutorado, UFRJ-IE.

LUNDVALL, B.-A. (1993). "Explaining inter-firm cooperation and innovation: limits of the transaction-cost approach." In GRAHBER, G. (ed.). The embedded firm: on the socio-economics of industrial networks. London: Routledge.

MARKUSEN, A. (1996). "Sticky places in slippery space: a typology of industrial districts." Economic Geography 72(3).

MONTEIRO FILHO, D. C. \& SANTOS, A. M. (2002). "Cadeia têxtil: estruturas e estratégias de comércio exterior.” BNDES Setorial 15: 113-36.

OLIVEIRA, M \& MAIA, K. \& OLIVEIRA, M (2004). "Arranjo produtivo local do vestuário da região de Umuarama-Cianorte no Estado do Paraná." Maringá: VII Encontro de Economia da Região Sul ANPEC SUL.

OLIVEIRA, Maria Aparecida. (2005). "Matriz Regional-econômica para o Estado do Paraná: Nova regionalização e segmentos industriais representativos.” SIMPÓSIO ALTERNATIVAS DE REGIONALIZAÇÃO COM VISTAS AO PLANEJAMENTO DO DESENVOLVIMENTO DO TERRITÓRIO, 4-5 novembro. Anais... Porto Alegre (RS), CD ROM.

PDI (2005). "Plano de Desenvolvimento Integrado do APL de Moda Bebê." URL: http://www.aplterraroxa.com.br. Acesso em: 10 de março de 2005.

PIKE, F. \& SENGENBERGER, W. (1992). Industrial districts and local economic regeneration. Genebra: International Institute for Labour Studies.

PROCHNIK, V. (2001). Cadeias produtivas na política de ciência, tecnologia e inovação. Rio de Janeiro: UFRJ.

PROCHNIK, V. (2002). Estudo da competitividade de cadeias integradas no Brasil: impactos das zonas de livre comércio cadeia têxtil e confecções. Rio de Janeiro: UFRJ.

PYKE, F. (1992). Industrial development through small firm cooperation: theory and practice. Genebra: International Labour Office.

RAIS/TEM (2004). Relação anual de informações sociais (RAIS/MTE) para os anos 2000 e 2004. Brasília: Ministério do Trabalho, CD-ROM.

RODRIGUES, R. \& MORETTO, A. \& GUILHOTO, J. (2002). "Cooperativas agropecuárias e estrutura produtiva paranaense: relações setoriais, emprego e renda nos anos 90.” Florianópolis: $V$ Encontro de Economia da Região Sul - ANPEC SUL.

SANTOS, F. \& CROCCO, M. \& LEMOS, M. (2002). “Arranjos e sistemas produtivos locais em 'espaços industriais' periféricos: estudo comparativo 
de dois casos brasileiros.” Texto para discussão. Belo Horizonte: UFMG/ Cedeplar.

SCHMITZ, H. (1998). Collective efficiency and increasing returns. Londres: Institute of Development Studies (IDS).

SCHMITZ, H. (2000). Local upgrading in global chains. Nota técnica 6. Rio de Janeiro: IE/UFRJ.

SEAB/DERAL (2004). Produção agropecuária municipal do Estado do Paraná. Curitiba: Secretaria de Estado da Agricultura e do Abastecimento, CD ROM.

SEFA (2004). Valor adicionado. Curitiba: Secretaria de Estado da Fazenda. Coordenação de Assuntos Econômicos, CD ROM.

STORPER, M. (1995). "The resurgence of regional economies, ten years later: the region as a nexus of untraded interdependencies." European Urban and Rregional Studies 2(3): 191-221.

SUZIGAN, W. (2000). "Aglomerações industriais como foco de políticas." Campinas: texto da Aula Magna do XXVIII Encontro Nacional de Economia da ANPEC.

SUZIGAN, W. (2001). Aglomeracões industriais: avaliação e sugestões de políticas. São Paulo: NEIT/IE-UNICAMP.

SUZIGAN, W. \& FURTADO, J. \& GARCIA, R. \& SAMPAIO, S. (2003). "Sistemas Locais de Produção: mapeamento, tipologia e sugestões de políticas.” Porto Seguro: XXXI Encontro Nacional de Economia da ANPEC.

VARGAS, M. A. (2000). "Local systems of innovation in developing countries: a study of technological learning in local productive arrangements in Brazil.” DRUID's Winter Conference on Industrial Dynamics.

Recebido em: 15 jun. 2006 Aceite em: 9 ago. 2006 